\title{
Polska a sprawa rumuńsko-sowieckiego paktu o nieagresji w latach 1931-1932 (2)
}

Zarys treści: Widoczny po rokowaniach w Rydze impas w rozmowach rumuńsko-sowieckich usiłował przezwyciężyć na rzecz Polski w kwietniu 1932 r. marszałek Józef Piłsudski. Nie zdołał jednak doprowadzić do zmiany nastawienia niechętnych rozmowom polityków rumuńskich, wspieranych w swym nastawieniu przez premiera Francji André Tardieu. Mimo zabiegów dyplomacji polskiej i francuskiej nie udało się wypracować formuły umożliwiającej wznowienie negocjacji. Objęcie przez Titulescu stanowiska szefa rumuńskiego Ministerstwa Spraw Zagranicznych ostatecznie przekreśliło perspektywy dojścia do skutku paktu Moskwa-Bukareszt. W tych okolicznościach dyplomacja polska, nie chcąc być traktowana instrumentalnie, w pozorowanych przez rumuńskiego ministra działaniach na rzecz zawarcia paktu zdystansowała się od dalszego pośredniczenia między Rumunią a Związkiem Sowieckim.

Outline of content: In April 1932, Marshal Józef Piłsudski attempted to solve the impasse, which marked the Romania-Soviet Union talks following the negotiations in Riga for the benefit of Poland. However, he never managed to alter the attitude of Romanian politicians, whose reluctance towards the talks was strongly supported by French Prime Minister André Tardieu. Despite the efforts of Polish and French diplomacy, no solution enabling the resumption of negotiations could be found. The appointment of Titulescu as head of the Romanian Ministry of Foreign Affairs eventually blighted the prospect of a pact between Moscow and Bucharest coming into life. In these circumstances, in order to avoid being treated instrumentally by the Romanian Foreign Minister in his pretended efforts towards the conclusion of a pact, the Polish diplomacy distanced itself from further mediation between Romania and the Soviet Union.

Słowa kluczowe: Polska, Rumunia, Związek Sowiecki, rumuńsko-sowiecki pakt o nieagresji, Rumunia 1931-1932, Nicolae Titulescu, stosunki polsko-rumuńskie w okresie międzywojennym

Keywords: Poland, Romania, Soviet Union, Romania-Soviet pact of non-aggression, Romania 1931-1932, Polish-Romania relations in interwar period 
W części pierwszej niniejszego artykułu ${ }^{1}$ przedstawiono realizację przez dyplomację polską przy poparciu Francji planu dyplomacji stworzenia bloku zachodnich sąsiadów ZSRR (Finlandia, Estonia, Łotwa, Polska i Rumunia) w związku z zawieraniem z tym państwem paktów o nieagresji. Urzeczywistnienie tego projektu napotkało znaczne trudności w Bukareszcie. Nie doceniano tam znaczenia powstania konstelacji stabilizującej sytuację w Europie Środkowo-Wschodniej. Dla Rumunów najważniejszą sprawą w relacjach z Moskwą było uznanie przynależności do Królestwa, Besarabii lub przynajmniej niekwestionowania tego faktu. Niemożność rozwiązania tego problemu w rozmowach z ZSRR prowadzonych w Rydze doprowadziła do impasu w kwestii zawarcia paktu.

W tej sytuacji w sprawę zaangażował się bezpośrednio marszałek Józef Piłsudski. Powracając z urlopu w Egipcie przez Rumunię, spotkał się on 14 kwietnia 1932 r. w Bukareszcie w towarzystwie posła RP Jana Szembeka z premierem Nicolae Iorgą i ministrem spraw zagranicznych Dimitrie Ghiką. Marszałek rozpoczął od bardzo gwałtownego ataku na Francję, której przywódcy - jak twierdził - „Z wzajemnej nienawiści, zmieniają linię polityczną z dnia na dzień”. Jako przykład wskazał Piłsudski pakt o nieagresji ze Związkiem Sowieckim - dzieło ministra spraw zagranicznych Aristidea Brianda, który jego następca André Tardieu ${ }^{2}$ wrzucił „do kosza na śmieci”. Marszałek podkreślał, iż to Paryż, a nie Polska, forsował koncepcję podpisania paktu, zmuszając ją do wznowienia negocjacji z ZSRR. Piłsudski deklarował, iż RP będzie w tej kwestii prowadziła politykę wynikającą z jej przymierza z Rumunią oraz wpływów, jakie posiadała w państwach bałtyckich. Marszałek informował o podjęciu na nowo negocjacji sowiecko-estońskich i o podpisaniu układów o nieagresji przez pozostałe państwa bałtyckie ${ }^{3}$. Zapowiedział też, iż jeśli Tallin układ podpisze, a Rumunia będzie podtrzymywać negatywne stanowisko, to Polska sfinalizuje swój pakt z ZSRR. Chcąc niejako osłodzić Bukaresztowi „gorzką pigułkę”, Piłsudski kładł nacisk na wartość paktu Brianda-Kellogga dla bezpieczeństwa Rumunii oraz możliwość jednoczesnej ratyfikacji paktu polsko-sowieckiego i rumuńsko-sowieckiego. W odpowiedzi Ghica stwierdził, iż Bukareszt w swoim nastawieniu względem negocjacji z ZSRR kieruje się nie stanowiskiem Francji, lecz racją stanu Rumunii. Wyrażał gotowość podjęcia rokowań z Sowietami, jednakże po wcześniejszym wynegocjowaniu warunków wstępnych przez Francję i Polskę, które powinny wystąpić w roli mediatorów. Domagał się gwarancji usunięcia $\mathrm{z}$ paktu wszelkich wzmianek o Besarabii oraz anulowania przez Moskwę wszystkich opinii prywatnych wypowiedzianych przez Sturdzę do Stomoniakowa ${ }^{4}$ oraz listu, który ten drugi przesłał pierwszemu. Szef rumuńskiej

1 Ukazał się w „Studiach z Dziejów Rosji i Europy Środkowo-Wschodniej”, tom XLIX, z. 2 (2014), s. $75-115$.

2 Briand stał na czele Quai d'Orsay od 23 lipca 1926 do 14 stycznia 1932 r., natomiast Tardieu od 23 lutego do 3 czerwca $1932 \mathrm{r}$.

3 Związek Sowiecki podpisał pakty o nieagresji z Finlandią 21 stycznia 1932 r., z Łotwą - 5 lutego t.r. i z Estonią - 5 maja t.r.

4 Mihai Sturdza (1886-1980) i Boris Stomoniakow (1882-1941) w styczniu 1932 r. prowadzili rozmowy w Rydze na temat rumuńsko-sowieckiego paktu o nieagresji. 
dyplomacji zastanawiał się, czy swoim wystąpieniem Piłsudski chciał wywrzeć presję na Rumunów i zmusić ich do podjęcia nowego dialogu z Moskwą, czy też jego decyzja w sprawie podpisania paktu z ZSRR była już ustalona. Ghica podkreślał, iż w tym drugim wypadku rząd polski powinien zdawać sobie sprawę, że podpisanie paktu bez czekania na Rumunię zostanie odebrane przez międzynarodową opinię publiczną jako osłabienie przymierza między obu krajami. Minister, komentując wystąpienie marszałka, wyraził przypuszczenie, że ten zrobił swój wypad przeciw Francji w celu odsunięcia od Polski jakichkolwiek podejrzeń, że jest nielojalna względem Rumunii i uczestniczy w „sowieckiej rozgrywce” dla jakichś profitów

Akcja Piłsudskiego zaktywizowała dyplomację rumuńską i francuską do dyskusji w sprawie podpisania przez Polskę paktu z ZSRR bez oglądania się na Bukareszt oraz w kwestii ewentualnych rokowań rumuńsko-sowieckich. Nicolae Titulescu, który w tym czasie usunął już zupełnie w cień ministra Ghikę i stał się czynnikiem miarodajnym w rumuńskiej polityce zagranicznej, odniósł się do wystąpienia marszałka bardzo krytycznie, nie unikając przy tym tonu egzaltacji. Podkreślał on, iż niezależnie od tego, czy Piłsudski zamierzał wywrzeć nacisk na Rumunię, czy też chciał pokazać swoje rzeczywiste intencje, to tak nie powinien postępować ze swoim sojusznikiem, ponieważ niszczy w ten sposób fundamentalną podstawę przymierza polsko-rumuńskiego, jaką jest wzajemne zaufanie. Wskazał, iż Polska postawiła na pierwszym planie interesy bloku bałtyckiego kosztem swojego rumuńskiego alianta, nie wnikając, czy negatywne nastawienie Bukaresztu do rozmów z Sowietami ma swoje uzasadnienie czy też nie. Jeśli Polska odmawia Rumunii pomocy w kwestii Besarabii, której obrona jest przecież przedmiotem sojuszu obu państw i nie chce zdystansować się od podpisania paktu z ZSRR, to w opinii Titulescu nie można wierzyć, że w sytuacji wojny Rumunii ze Związkiem Sowieckim udzieli jej pomocy militarnej i materialnej. Zdaniem rumuńskiego dyplomaty, podpisanie przez Warszawę paktu z Sowietami będzie wypowiedzeniem aliansu. Titulescu zalecał, aby Polsce uświadomić szkodliwość tej polityki, ale w żadnym wypadku nie prosić jej o niepodpisywanie paktu, ponieważ jeśli tak by się stało, to będzie ona domagać się zapłaty za swoje poświęcenie, które byłoby, według rumuńskiego polityka, niczym innym, jak tylko wypełnieniem przez nią obowiązków sojuszniczych ${ }^{6}$.

5 Telegram Ghiki z 14 IV 1932 do poselstw w Paryżu, Warszawie, Rydze i przedstawicielstwa w Genewie, Arhivele Ministerului Afacerilor Externe, București (dalej: AMAE). 71/1920-1944, U.R.S.S. Vol. 68, k. 136-136a; notatka ze spotkania Iorgi i Ghiki z Piłsudskim i Szembekiem 14 IV 1932, Behind closed doors. Secret papers on the failure of Romanian-Soviet negotiations 1931-1932, tłum. i wstęp W. M. Bacon, Stanford 1979, s. 97-99; A.-M. Mironov, Vremea încercărilor. Relațiile româno-sovietice 1930-1940, București 2013, s. 111; D. Hrenciuc, România şi Polonia 1932-1939. Relaţii politice şi diplomatice, Iaşi 2005, s. 24; A. Skrzypek, Zagadnienia rumuńskie w stosunkach polsko-radzieckich w latach 1932-1938. Z dziejów stosunków polsko-radzieckich (dalej: ZDSPR), t. XI-XII, Studia i materiały, Warszawa 1975, s. 191-192; zob. H. Bułhak, Polska a Rumunia 1918-1939, [w:] Przyjaźnie i antagonizmy. Stosunki Polski $z$ państwami sąsiednimi w latach 1918-1939, red. J. Żarnowski, Warszawa 1977, s. 329; V. Moisuc, Premisele izolării politice a României 1919-1940, București 1991, s. 326.

6 Telegram Titulescu do MSZ z 22 IV 1932, Behind..., s. 100-101; telegram Szembeka do MSZ z 8 IV 1932, Hoover Institution Archives (dalej: HIA). Polska. Poselstwo (Rumunia) (dalej: Rumunia). 
W takim duchu Titulescu na początku trzeciej dekady kwietnia miał prowadzić wymianę zdań z przebywającym w Genewie ministrem spraw zagranicznych RP Augustem Zaleskim, który jakoby poinformował go, że nie był w żaden sposób odpowiedzialny za oświadczenie Piłsudskiego. Jego treść przypisywał dyplomata rumuński, zapewne za sprawą sugestii Zaleskiego, wpływowi na marszałka wiceministra spraw zagranicznych Józefa Becka. Zaleski obiecał swemu interlokutorowi, iż po powrocie do Warszawy będzie odradzał Piłsudskiemu podpisanie paktu z Moskwą z pominięciem Bukaresztu. Szef polskiego MSZ, nawiązując do swojego wcześniejszego spotkania z Titulescu 15 kwietnia, w którym ten domagał się cofnięcia przez Rosjan listu Stomoniakowa jako warunku wstępnego negocjacji, poinformował Rumuna o swoich sondażach czynionych względem ludowego komisarza spraw zagranicznych Maksima Litwinowa i o odniesionym wrażeniu, że jest on skłonny wycofać list. Inklinacje te Zaleski przypisywał obawom ZSRR przed dalszą ekspansją Japonii na Dalekim Wschodzie i chęcią zabezpieczenia się w Europie poprzez zawarcie paktów o nieagresji. Gospodarz Wierzbowej liczył zapewne na dojście do skutku spotkania Titulescu z Litwinowem; rozmawiał o tym z rumuńskim dyplomatą 15 kwietnia, a ten obiecał zapytać Bukareszt o zgodę. Nie uczynił jednak tego. Zakomunikował jedynie Ghice swoją negatywną odpowiedź daną Zaleskiemu na spotkaniu w początkach trzeciej dekady kwietnia. W tym czasie natomiast Zaleski ustalił z szefem $\mathrm{NKID}^{7}$, iż w sprawie paktu rumuńsko-sowieckiego nastąpi spotkanie ich obu na dworcu w Berlinie ${ }^{8}$.

Titulescu, zalecając bukareszteńskiemu MSZ unikanie bezpośredniej interwencji w Warszawie w sprawie powstrzymania Polski przed podpisaniem paktu z ZSRR, poinformował o akcji Piłsudskiego polityków francuskich $\mathrm{z}$ oczywistą intencją wywarcia tą drogą presji na Wierzbową. W rozmowie z premierem Tardieu dyplomata rumuński wskazał, iż konsekwencją polityczną podpisania przez Polskę paktu z Moskwą bez Rumunii będzie zagrożenie przymierza. Przedstawił też warunki wstępne podjęcia rozmów rumuńsko-sowieckich, których uzgodnienie z Moskwą miało być zadaniem dyplomacji polskiej i francuskiej. Było to wycofanie listu Stomoniakowa do Sturdzy i niewzmiankowanie w jakikolwiek sposób o sporze besarabskim. Premier francuski uznał za właściwe stanowisko swego rozmówcy i poinformował go, iż na wieść o akcji Piłsudskiego polecił wyrazić wobec Wierzbowej dezaprobatę z powodu podpisywania paktu bez Rumunii. Tardieu wspomniał też, że

Księga szyfrów (dalej: Ks. szyf.) nr 6, pudło (dalej: p.) 2, folder (dalej: f.) 3; A.-M. Mironov, op. cit., s. 111; zob. też pismo Ghiki do Cesianu z 27 IV 1932, Behind..., s. 105-107.

7 Narodnyj komissariat inostrannyh del SSSR (dalej: NKID) - Ludowy Komisariat Spraw Zagranicznych ZSRR (dalej: LKSZ).

8 Telegram Becka do poselstwa w Bukareszcie z 15 IV 1932, nr 3, HIA. Rumunia. Telegramy osobiste Pana Posła. Książka Nr 1, 1931-1933 (dalej: HIA. Rumunia. Tel. osob. ks. 1), p. 3, f. 5; telegram Titulescu do MSZ z 22 IV 1932, Behind..., s. 102-104; telegram Szembeka do MSZ z 25 IV 1932, nr 41, HIA. Rumunia. Ks. szyf., nr 6, p. 2, f. 3; pismo Massigliego do Berthelota z 24 V 1932, La Grande Roumanie alliée de la France. Une péripétie diplomatique des Années Folles? (1919-1933), oprac. T. Sandu, Montréal 1999, s. 228-230. 
w niedawnej rozmowie z Litwinowem zaznaczył, iż próba wymuszenia przez ZSRR na Rumunii uznania istnienia sporu besarabskiego spowoduje niepodpisanie przez Francję paktu z Moskwą. Szef rządu III Republiki pytał swego współrozmówcę, czy po spełnieniu przez Litwinowa warunków wstępnych, Francuzi będą mogli podjąć opracowanie szkicu paktu o nieagresji. Titulescu odpowiedział twierdząco, pod warunkiem swojego uczestnictwa w zespole redagującym pakt i uzgadniania z nim treści szkicu przed wysłaniem do Moskwy jako francuskich propozycji. Niechętny Moskwie Tardieu zaaprobował tę propozycję?. Takie stanowisko w pełni odpowiadało Titulescu, gdyż dawało możliwości dalszego uchylania się od rokowań z ZSRR.

Potwierdzeniem tego może być jego postawa wobec Quai d'Orsay, które w dalszym ciągu za sprawą Berthelota podejmowało wysiłki na rzecz wznowienia rokowań rumuńsko-sowieckich, poszukując formuły, która jednocześnie nie niosłaby uznania przez ZSRR implicite zajęcia Besarabii i nie podkreślałaby kontrowersyjności posiadania przez Rumunów tej prowincji. Titulescu na propozycję Francji interwencji wobec Rosjan w tej sprawie złożoną w początkach trzeciej dekady kwietnia stwierdził, iż jest to podobnie jak Polski i jej obowiązkiem sojuszniczym. Dyplomata rumuński do warunków wstępnych, które już sformułował wobec Tardieu, dodał jeszcze zdefiniowanie pojęcia agresji oraz określenie geograficzne terytorium, które miałoby podlegać zabezpieczeniu ${ }^{10}$. W początkach maja Quai d'Orsay przekazało Titulescu, z prośbą o opinię, opracowany przez siebie projekt sowiecko-rumuńskiego paktu o nieagresji. We francuskim MSZ zdawano sobie sprawę, iż może on nie wzbudzić uznania w oczach rumuńskiego dyplomaty, stąd też poproszono o przedstawienie jego własnej propozycji. Titulescu obiecał rzecz przestudiować, podnosząc jednocześnie sprawę potwierdzenia na piśmie przez Rosjan unieważnienia listu Stomoniakowa, do czego jego rozmówca René Massigli - wysoki urzędnik Quai d’Orsay - odniósł się ze sceptycyzmem. Dyplomata rumuński skrytykował Francję za działania na rzecz zawierania przez limitrofów paktów o nieagresji z Moskwą. W jego opinii dyplomacja sowiecka mogła chcieć poprzez podpisanie paktów doprowadzić do rozbrojenia tych państw, szermując argumentem, że ich bezpieczeństwo dzięki tym układom zostało zapewnione. Istniało też według niego prawdopodobieństwo, że ZSRR traktuje zawieranie paktów w kategoriach polityki długofalowej, wówczas obowiązkiem Francji było, zdaniem Titulescu, wykorzystanie tej koniunktury dla uzyskania od Moskwy ostatecznego uznania przynależności Besarabii do Rumunii. Można sądzić, iż te wynurzenia Titulescu były przyczyną oświadczenia skierowanego przez Quai d’Orsay pod adresem Palatul Sturdza, w którym stwierdzano, że Francja nie wysuwa zastrzeżeń odnośnie do kwestii realizacji przez Bukareszt paktu o nieagresji z ZSRR, nie życzy też sobie, by rząd rumuński zasłaniał się stanowiskiem Francji w tej sprawie, gdyż to on musi ocenić sytuację i podjąć odpowiednią decyzję. Oświadczenie to kilkanaście dni

9 Telegram Titulescu do MSZ z 22 IV 1932, Behind..., s. 101-104.

10 Telegram Cesianu do MSZ z 18 IV 1932, ibidem, s. 99-100; telegram Dowgalewskiego do Litwinowa z 19 IV 1932, Dokumenty vneshnei politiki SSSR, t. XV: 1 yanvarya-31 dekabrya 1932 g., red. G. K. Deev i in., Moskva 1969 (dalej: DVP, t. XV), s. 256; telegram Titulescu do MSZ z 22 IV 1932, Behind..., s. 103-104; zob. też telegram Cesianu do MSZ z 25 IV 1932, ibidem, s. 104-105. 
później zostało uzupełnione stwierdzeniem francuskiego MSZ, że dla Rumunii nie będzie korzystne przyjęcie w sprawie paktu z ZSRR innego stanowiska niż Polska ${ }^{11}$. Enuncjacje Quai d’Orsay należy odbierać jako próbę zwiększenia presji na Rumunii poprzez ukazanie groźby izolacji w wypadku podpisania paktu z Moskwą przez Polskę i Francję. Charakterystyczne, iż ze strony Paryża nie płynęły już do Warszawy sygnały o dezaprobacie wobec planów podpisania przez nią paktu z Moskwą bez Rumunii, natomiast kierowano znad Sekwany impulsy wobec Bukaresztu sugerujące ujednolicenie $w$ tej kwestii stanowiska $\mathrm{z}$ Polską. Można sądzić, iż to przesunięcie akcentów w działaniach francuskiego MSZ wiąże się z wynikami wyborów parlamentarnych we Francji (odbyły się w dwóch turach - 1 i 8 maja 1932 r.), w których zwycięstwo odniosły francuskie ugrupowania lewicowe. Oznaczało to ustąpienie Tardieu (którego twarde warunki stawiane ZSRR w kwestii podpisania paktu ośmielały Rumunów do uchylania się od negocjacji) i przejęcie rządów przez Herriota znanego ze swoich sympatii do Związku Radzieckiego.

Rumuni byli pod wrażeniem tych zmian. Król Karol II oraz część ministrów z rządu Iorgi zaczęli skłaniać się ku wznowieniu rokowań ze Związkiem Sowieckim. Za ich sprawą 12 maja udał się do Genewy Victor Cădere - nowy (od 16 kwietnia 1932 r.) rumuński poseł $\mathrm{w}$ Warszawie - $\mathrm{z}$ zadaniem wpłynięcia na zmianę nieprzejednanego stanowiska Titulescu w sprawie paktu rumuńsko-sowieckiego. Nie wierzył on w sukces swej misji i jego przewidywania okazały się słuszne. Tuż przed wyjazdem poseł rumuński w rozmowie z radcą poselstwa RP w Bukareszcie Tadeuszem Kobylańskim wskazywał, iż rokowania z ZSRR należałoby rozpocząć na nowej podstawie, likwidując błędy popełnione w Rydze przez Sturdzę. Tymczasem rumuńskie MSZ wzdragało się przed wznowieniem bezpośrednich negocjacji z ZSRR. 16 maja sekretarz generalny rumuńskiego MSZ - Gheorghe Filality - w rozmowie z Szembekiem wyraził co prawda gotowość podpisania paktu, ale dopiero po uzgodnieniu tekstu z ZSRR przez „zaprzyjaźnioną z Rumunią stronę”, czyli przez Polskę lub Francję, który nie zawierałby wzmianki o kwestii Besarabii. Krótko po tej rozmowie w prasie rumuńskiej ukazała się informacja o oficjalnej propozycji Polski pośrednictwa w tej sprawie skierowanej do bukareszteńskiego MSZ. Szembek ustalił, iż informacja wyszła od Filality’ego i odebrał ją jako kolejną próbę storpedowania przez Rumunów paktu z ZSRR. Interwencja u premiera Iorgi spowodowała dementi. Niemniej poseł RP uznał, iż „Ghica, Iorga i Titulescu nadal lekceważą i nie rozumieją znaczenia dla Rumunii paktu i nadal świadomie go sabotują". Szembek sugerował Warszawie złożenie rządowi w Bukareszcie deklaracji „kategorycznej i oficjalnej”, która zawierałaby stanowisko Polski w sprawie jej paktu z ZSRR z wyeksponowaniem zamiaru jego podpisania oraz stwierdzenie, że od tej chwili przestaje się ona kwestią układu „rosyjsko-rumuńskiego interesować, pozostawiając [Rumunii], (...) całkowitą inicjatywę" ${ }^{\prime 2}$.

11 Telegram Titulescu do MSZ z 5 V 1932, ibidem, s. 107-108; telegram Kobylańskiego do MSZ z 9 V 1932, nr 47, HIA. Rumunia. Ks. szyf., nr 6, p. 2, f. 3; telegram Szembeka do MSZ z 21 V 1932, nr 54, ibidem.

12 Telegram Kobylańskiego do MSZ z 12 V 1932, nr 49, ibidem; telegram Szembeka do MSZ z 19 V 1932, nr 52, ibidem (stąd cytat); Â. Kopanskij, I. Ė. Levit, Sovetsko-rumynskie otnošeniâ 1929-1934 gg. (ot podpisaniâ Moskovskogo protokola do ustanovleniâ diplomatičeskih otnošenij), Moskva 1971, s. 96. 
Szembek zapewne nie uzyskał zgody Wierzbowej na tak zdecydowane posunięcie. Warszawa nadal skłonna była podejmować wysiłki na rzecz wypracowania płaszczyzny negocjacji rumuńsko-sowieckich. 20 maja poseł RP na spotkaniu $\mathrm{z}$ Ghiką przedstawił propozycję kompromisu w sprawie besarabskiej w formie deklaracji ułożonej przez posła Patka. Stwierdzała ona, że „wszystkie sporne sprawy między obiema układającymi się stronami pozostają na boku i przez podpisanie paktu o nieagresji żadna z nich ani stracić, ani zyskać nie może”. Rumuńskiemu ministrowi spraw zagranicznych formuła ta wydawała się do przyjęcia. Bez opinii Titulescu nie chciał on jednak podejmować ostatecznej decyzji. Zwracał też uwagę, że jego kraj mógłby podpisać pakt, jedynie „o ile by wszystko zostało przez stronę trzecią z Sowietami uzgodnione”. Ze względu na wagę sprawy i konieczność pośpiechu Szembek sugerował Warszawie wysłanie do Genewy Patka dla omówienia sprawy z Titulescu. Wskazywał, że jako bezpośredni partner Litwinowa i prawnik mógłby łatwiej trafić ze swoimi argumentami do rumuńskiego dyplomaty i go przekonać13.

24 maja doszło do planowanego spotkania Zaleskiego z Litwinowem w Berlinie. Wcześniej szef polskiej dyplomacji konsultował z Titulescu kwestie, o jakich powinien rozmawiać z Litwinowem. Dyplomata rumuński wskazał na sprawę uznania przyłączenia Besarabii do Rumunii. Zaleski zaoponował, stwierdzając, że jest to niemożliwe. Wówczas Titulescu wysunął dezyderat uzyskania wycofania listu Stomoniakowa i zapowiedział poszukiwanie formuły obejmującej przypadek agresji na Besarabię. Jak widać, w kluczowej kwestii Titulescu uchylił się od sformułowania konkretnej propozycji. Przed berlińskim spotkaniem Zaleski dyskutował jeszcze z Berthelotem o niektórych sformułowaniach mogących być do przyjęcia przez Rosjan i Rumunów. Nie były one uzgodnione z Rumunami być może $\mathrm{w}$ obawie przed zanegowaniem. W trakcie rozmowy $\mathrm{z}$ Litwinowem minister spraw zagranicznych RP skonstatował, iż król Karol i minister Ghica obecnie bardziej przychylnie odnoszą się do zawarcia paktu aniżeli wcześniej. Wspomniał też, że Piłsudski zagroził Rumunom samodzielnym podpisaniem przez Polskę paktu z ZSRR $w$ razie ich dalszego uporu. Zaleski uzyskał od szefa NKID deklarację, iż w przypadku finalizacji paktu rumuńsko- sowieckiego cała korespondencja dotycząca negocjacji w Rydze zostanie uznana za niebyłą. Gospodarz Wierzbowej we własnym imieniu zaproponował zastąpienie w artykule I rumuńskiej wersji paktu słowa „suwerenność" przez słowo „władza”. Do preambuły natomiast chciał wprowadzenia „deklaracji Patka”. Litwinow w odniesieniu do tych propozycji zastrzegł sobie czas do namysłu, z miejsca jednak wyrażając życzenie zamiany w „deklaracji Patka” słów „na boku” przez „otwarte”. Zaleski poinformował Litwinowa, iż chciałby, żeby negocjacje sowiecko-rumuńskie rozpoczęły się ok. 15 czerwca. Ponieważ szef polskiego MSZ oceniał Titulescu jako „bardzo ciężkiego i histerycznego człowieka”, uznał, iż dobrym rozwiązaniem byłoby przygotowanie gruntu do negocjacji przez

13 Telegramy Szembeka do MSZ z 20 V (nr 53 - drugi cytat), 23 V (nr 55 - pierwszy cytat) 1932, HIA. Rumunia. Ks. szyf., nr 6, p. 2, f. 3. 
posła Cădere, który - jak już wspomniano - bezskutecznie przekonywał delegata Rumunii przy Lidze Narodów do negocjacji z Sowietami ${ }^{14}$.

28 maja poseł Szembek poinformował Ghikę o rezultatach spotkania Zaleskiego z Litwinowem. Rumuński minister przyjął do wiadomości sprawozdanie, nie odnosząc się doń merytorycznie. Dał on posłowi RP do zrozumienia, iż decyzje w tej kwestii zależą od stanowiska Titulescu. W opinii Ghiki mógłby wpłynąć na to stanowisko poseł Patek, gdyby udał się do Genewy i poinformował delegata rumuńskiego przy Lidze Narodów o „metodach działania i nastrojach Litwinowa”. Tymczasem Titulescu ocenił efekty spotkania bardzo krytycznie. Uznał, że Zaleski nie powinien czynić we własnym imieniu żadnych propozycji. Negatywnie odniósł się do sformułowania $\mathrm{z}$,deklaracji Patka” o „spornych sprawach miedzy obu układającymi się stronami", twierdząc, że i tak oznacza to Besarabię, o której wzmianki miało nie być. Efekty rozmów były zatem dla niego nie do przyjęcia, natomiast postępowanie Zaleskiego uznał za nierozważne ${ }^{15}$.

Brak inklinacji Rumunów do rozmów z Sowietami, kryzys rządowy w Bukareszcie, który ich raczej nie przybliżał oraz zbliżający się termin ratyfikacji paktów z ZSRR przez parlamenty Estonii i Łotwy spowodowały kolejne naciski ze strony Warszawy na Bukareszt. Z polecenia Zaleskiego Szembek miał oświadczyć nowemu rządowi w Bukareszcie po jego ukonstytuowaniu się, iż Polska „stoi niezmiennie na stanowisku doprowadzenia do zawarcia paktu" rumuńsko-sowieckiego, odkładając podpisanie swojego paktu z ZSRR do połowy czerwca, aby umożliwić Rumunii osiągnięcie porozumienia z Moskwą. Jak pamiętamy, w trakcie spotkania Zaleski-Litwinow w Berlinie zakładano rozpoczęcie rozmów rumuńsko-sowieckich ok. 15 czerwca i dopiero po ich zakończeniu miał być podpisany układ polsko-sowiecki. Było to więc skrócenie terminu, który - jak się wydaje - należy traktować jako element nacisku na Bukareszt. Poseł RP miał też zadeklarować niepodejmowanie od tej chwili przez Warszawę „żadnych nowych kroków pośredniczących” i nieczynienie „dalszych starań w kierunku doprowadzenia do paktu rumuńsko-sowieckiego". Szembek otrzymał również upoważnienie do stwierdzenia, iż rząd rumuński sam teraz będzie musiał „pracować nad obroną interesów swego państwa”16.

Nim doszło do złożenia wspomnianego oświadczenia wobec nowego rządu, sprawa pertraktacji rumuńsko-sowieckich została podjęta 7 czerwca, po śniadaniu, które

14 Pismo Massigli do Berthelota z 24 V 1932, La Grande Roumanie alliée..., s. 229-230; notatka z rozmowy Litwinowa z Zaleskim z 24 V 1932, DVP, t. XV, s. 330-331; telegram Becka do Genewy do MSZ z 25 V 1932, Polskie Dokumenty Dyplomatyczne (dalej: PDD) 1932, red. K. Kania, Warszawa 2011, s. 317; notatka z 26 V 1932, AAN. Delegacja RP przy Lidze Narodów w Genewie (dalej: Delegacja RP), t. 134, k. 20; A. Skrzypek, Zagadnienia rumuńskie..., s. 192; A. Sheviakov, Sovetsko-rumynskie otnošeniâ i problema evropejskoj bezopasnosti 1932-1939, Moskva 1977, s. 34; Â. Kopanskij, I. Ė. Levit, op. cit., s. 34; zob. też telegram Szembeka do MSZ 28 V 1932, nr 59, HIA. Rumunia. Ks. szyf., nr 6, p. 2, f. 3.

15 Telegram Titulescu do MSZ z 26 V 1932, Behind..., s. 109; telegram Szembeka do MSZ z 28 V 1932, nr 58, HIA. Rumunia. Ks. szyf., nr 6, p. 2, f. 3; zob. G. Gafencu, Însemnări politice 1929-1939, ediţie şi postfaţă de S. Neagoe, Bucureşti 1991, s. 303-304.

16 Telegram Zaleskiego do poselstwa w Bukareszcie z 1 VI 1932, nr 64, HIA. Rumunia. Ks. szyf., nr 6, p. 2, f. 3 . 
wydał król Karol z okazji przybycia do Bukaresztu polskiego szefa Sztabu Głównego, gen. Janusza Gąsiorowskiego. W spotkaniu uczestniczyli także Titulescu, Szembek i gen. Nicolae Samsonovici - szef Sztabu Generalnego armii rumuńskiej. Polski punkt widzenia, opierający się na przedstawionym już oświadczeniu Zaleskiego, przedstawił gen. Gąsiorowski, powołując się przy tym na upoważnienie Piłsudskiego. Następnie głos zabrał Titulescu, podnosząc sprawę listu Stomoniakowa, której sposób załatwienia niezbyt go satysfakcjonował, choć, zdaniem Szembeka, gotów był przejść nad tym do porządku dziennego. Zaakceptował zamianę słów „suwerenność" na „władza”. Kategorycznie natomiast odrzucał „deklarację Patka”. Miał też pretensje do Polaków, że idąc w kwestii paktu „z Bałtami, a nie z Rumunią, moralnie osłabiają alians". Król poparł wywody swego przedstawiciela w Genewie, podkreślając, iż uważa pakt rumuńsko-radziecki za niefortunne pociągnięcie. W jego opinii, „cały rosyjski manewr paktowy polega na tym, aby przyjść na konferencję rozbrojeniową z gotowymi paktami i móc na tej podstawie stawiać większe żądania i wzmocnić swoją tezę". Karol II nie odrzucał jednak całkowicie paktu. Odpowiadając na pytanie Szembka, czy w razie znalezienia formuły kompromisowej byłby skłonny pozwolić na podpisanie paktu, odpowiedział, że „bardzo niechętnie”. Zarówno Szembek, jak i gen. Gąsiorowski odnieśli wrażenie, że król bardziej skłania się ku paktowi niż Titulescu. W toku dalszej dyskusji gen. Samsonovici podniósł jeszcze złe wrażenie, jakie wywarłoby na rumuńskiej opinii publicznej podpisanie paktu przez Polskę, bez oglądania się na Rumunię ${ }^{17}$.

11 czerwca Szembek przedstawił swoje oświadczenie Alexandru Vaida-Voevodowi - premierowi nowo utworzonego rządu oraz podsekretarzowi stanu w MSZ - Grigore Gafencu, uzupełniając je jeszcze rozbudowaną argumentacją. Zapewne ze względu na kryzys rządowy w Bukareszcie i przesunięcie terminu swojego oświadczenia poseł RP jako datę przewidywanego podpisania przez Polskę paktu z ZSRR wymienił drugą połowę czerwca, co Rumuni zinterpretowali jako okres między 15 a 25 tego miesiąca. W uzasadnieniu tej decyzji Szembek stwierdził, iż polityka Polski wobec ZSRR zawsze opierała się na dwóch czynnikach: współpracy z Rumunią i kooperacji z państwami bałtyckimi. Współpraca $\mathrm{z}$ Rumunią według posła RP była zapewniona przez traktat przymierza, którego znaczenie zostało nawet wzmocnione poprzez artykuł 3 polsko-sowieckiego paktu o nieagresji, stwierdzający, iż traktaty sojusznicze obu umawiających się stron pozostają w mocy. Ponieważ z państwami bałtyckimi Polska nie ma układu sojuszniczego, przeto pragnie - kontynuował poseł - wyrazić z nimi swoją solidarność przez wspólne działania wobec Moskwy. Ze względu na zbliżającą się ratyfikację przez parlamenty w Tallinie, Rydze i Helsinkach traktatów o nieagresji ze Związkiem Radzieckim, Polska dla dotrzymania kroku zmuszona byłaby wcześniej podpisać własny pakt. Po tym stwierdzeniu Szembek jeszcze raz mocno podkreślał poważne traktowanie przez Polskę zobowiązań wynikających

17 Telegram Szembeka do MSZ z 8 VI 1932, nr 63, ibidem (stąd cytaty); Wizyta misji wojskowej w Bukareszcie, „Gazeta Polska” 14 VI 1932; M. Wołos, Francja - ZSRR. Stosunki polityczne w latach 1924-1932, Toruń 2004, s. 575. 
z przymierza z Rumunią. Świadczyła o tym, zdaniem posła, demonstracyjna wizyta złożona przed dwoma miesiącami w Kiszyniowie przez marszałka Piłsudskiego, będąca wyrazem solidaryzowania się z rumuńską polityką w kwestii Besarabii. W odpowiedzi rumuńscy politycy podkreślali, iż nowy rząd ma najlepszą wolę osiągnięcia porozumienia $\mathrm{z}$ Moskwą, jednakże ze względu na krótki termin nie do przyjęcia jest rozpoczęcie z nią pertraktacji przed 15 czerwca. Ewentualne zaś zainicjowanie rokowań pod presją tej daty musiałoby osłabić pozycję negocjacyjną Rumunii. Rozmówcy prosili Szembeka o przesuniecie przez Polskę terminu podpisania paktu, gdyż Rumunia znajduje się na półmetku kampanii wyborczej i nie byłoby dobrze $\mathrm{w}$ takim okresie osłabiać wiarę w sojuszników, gdyż mogą na tym skorzystać wrogowie przymierza obu państw. Postulowano przesunięcie podpisania paktu przez Polskę na okres po wyborach, czyli o miesiąc, deklarując podjęcie w tym czasie prac nad znalezieniem odpowiedniej formuły porozumienia rumuńsko-sowieckiego. Podkreślano, iż niezrealizowanie tego postulatu zostanie przez miejscową opinię publiczną ocenione jako osłabienie sojuszu polsko-rumuńskiego. Szembek usiłował polemizować z tą argumentacją. Zaznaczył, iż teren dla rozmów Titulescu z Litwinowem został już przygotowany przez dyplomację polską i można je rozpocząć w każdej chwili. Jego zdaniem, polska opinia publiczna fakt niedojścia do skutku paktu rumuńsko-sowieckiego mogłaby odebrać jako brak solidarności Rumunii z RP, stąd też należy tak pokierować opinią publiczną w obu krajach, aby „alians na tym jak najmniej ucierpiał”. Poseł RP, oficjalnie wyrażając sceptycyzm odnośnie do uzyskania tak długiej zwłoki Warszawy, jeśli idzie o termin podpisania paktu, zgodził się prośbę Bukaresztu przesłać na Wierzbową. Vaida-Voevod był większym optymistą. Uznał on bowiem, że ze względu na ważkość powodów przedstawionych przez Rumunów Polska zrezygnuje z terminu, o którym wspominał Szembek ${ }^{18}$.

Żywiąc to przekonanie, rumuński premier nie zaniechał dalszego oddziaływania w tej sprawie na Polaków. 14 czerwca Cădere w Warszawie w rozmowie z Beckiem, a Gafencu w Bukareszcie z Szembekiem usiłowali przekonać polskich dyplomatów o konieczności przesunięcia terminu podpisania przez Polskę paktu z ZSRR do czasu sfinalizowania rozmów rumuńsko-sowieckich. Poseł rumuński powtarzał argumeny o zaawansowanej kampanii wyborczej w Regatul României i niekorzystnym wrażeniu, jakie musiałoby wywołać nie tylko u miejscowej opinii publicznej, ale także u francuskiej, podpisanie paktu polsko-sowieckiego bez czekania na Bukareszt. W odpowiedzi Beck wspomniał o znanych uwarunkowaniach, które postawiły rząd RP w sytuacji niemożności dalszego odkładania podpisania paktu, który od pięciu miesięcy był parafowany. Wiceminister powtórzył również zastrzeżenia marszałka Piłsudskiego wyrażane w czasie jego wiosennej

18 Telegram Szembeka do MSZ z 11 VI 1932, nr 64, HIA. Rumunia. Ks. szyf., nr 6, p. 2 , f. 3; Memorandum Gafencu z 11 VI 1932, AMAE. 71/1920-1944, U.R.S.S. Vol. 68, k. 145-148; A. Vaida-Voevod, Memorii, Vol. II, prefaţă, ediţie îngrijită, note şi comentarii de A. Şerban, Cluj-Napoca 2006, s. 234; G. Gafencu, op. cit., s. 303; A.-M. Mironov, op. cit., s. 112-113. 
wizyty w Bukareszcie. Beck, jak zaobserwował Cădere, był pod wrażeniem napięć w stosunkach z Wolnym Miastem Gdańskiem ${ }^{19}$ oraz zdymisjonowania kanclerza Heinricha Brüninga przez prezydenta Paula Hindenburga i powołania nowego rządu Franza von Papena składającego się z elementów prawicowych wrogo nastawionych do RP. Dlatego raczej nie chciał odkładać podpisania paktu z Moskwą, który mógłby zwiększyć bezpieczeństwo granicy wschodniej RP. O wzrastającej wrogości Niemiec do Polski zdawała się świadczyć - obserwowana przez Szembeka nad Dambovitą - antypolska akcja propagandowa prowadzona przez niemieckiego chargé d’affaires Johannesa Kirchholtesa, zmierzająca do wytworzenia nieufności między Bukaresztem a Warszawą, poprzez lansowanie opinii, że Polska pozostawi Rumunię swemu losowi.

Początkowo dyplomaci polscy stali na stanowisku podjęcia w Genewie przez Titulescu możliwie szybko rokowań z Litwinowem, gdyż teren - jak uważali - został już przez nich przygotowany. Ulegli jednak życzeniu Rumunuów, aby wcześniej Zaleski spotkał się z szefem NKID dla wybadania jego zamiarów. Jeśli perspektywa finalizacji rozmów rumuńsko-sowieckich okazałaby się bliska, Wierzbowa zgadzała się dać Rumunom czas konieczny na doprowadzenie do skutku paktu z ZSRR, w przeciwnym wypadku nie zamierzała ona dłużej opóźniać podpisania. Tymczasem Gafencu poinformawał posła RP o rozmowie z Titulescu, który wyraził gotowść zaakceptowania w preambule „deklaracji Patka”. Szembek donosił, że Rumuni biorą również pod uwagę formułę nieco inaczej brzmiącą, lecz odpowiadającą sformułowaniom Patka; miałaby ona stwierdzać, że „obecny traktat (pakt) o nieagresji nie przynosi żadnego uszczerbuku (nie może zmieniać niczego) w obecnej sytuacji między dwoma umawiającymi się stronami”. Rumuni pragnęli umieścić w artykule I, ustęp 2, określenie geograficzne obszaru, gdzie za sprzeczny z zasadą nieagresji uznawano by „każdy atak poza Dniestr i wybrzeże Morza Czarnego”. Na stwierdzenie Szembeka, iż Rosjanie odmówią zaakceptowania tej formuły - jak to już miało miejsce w Rydze - Gafencu zaproponował uznanie za sprzeczny z zasadą nieagresji „wszelki atak na terytoria znajdujące się pod władzą obu umawiajacych się stron". W ocenie posła RP w Bukareszcie rysująca się formuła negocjacji napawała optymizmem, zwłaszcza wobec - jak mu się wydawało - zmiany negatywnego stanowiska Titulescu odnośnie do „deklaracji Patka”20.

191 lipca 1931 r. władze Wolnego Miasta Gdańska wypowiedziały umowę z Polską o stacjonowaniu w porcie gdańskim polskich okrętów wojennych, co było uszczupleniem jej praw gwarantowanych traktatem wersalskim. W odpowiedzi władze w Warszawie nakazały, aby niszczyciel Wicher, mający pełnić honory gospodarza w trakcie wizyty brytyjskich okrętów wojennych, wpłynął na redę portu i w razie obrazy polskiej bandery otworzył ogień do najbliższego urzędowego gmachu w Gdańsku. Do użycia broni nie doszło, natomiast demonstracja okazała się skuteczna. 13 sierpnia 1932 r. władze W. M. Gdańska zgodziły się na przedłużenie umowy. J. Krasuski, Tragiczna niepodległość. Polityka zagraniczna Polski w latach 1919-1945, Poznań 2000, s. 186.

20 Pismo Cădere do Vaida-Voevoda z 14 VI 1932, Behind..., s. 115-117; memoranda Gafencu z 16 i 17 VI 1932, ibidem, s. 112-114, 117-118; telegram Becka do Zaleskiego do Genewy z 15 VI 1932, AAN. Delegacja RP, t. 134, k. 22; telegram Szembeka do MSZ z 18 VI 1932, nr 68, HIA. Rumunia. Ks. szyf., nr 6, p. 2, f. 3 (stąd cytaty); G. Gafencu, op. cit., s. 304-305; A.-M. Mironov, op. cit., s. 113-114; 
Rumuni strali się wpływać na stanowisko Warszawy także poprzez Quai d'Orsay. Na polecenie centrali ambasador francuski w Warszawie Jules Laroche wystąpił wobec Becka $\mathrm{z}$ démarche mającym na celu przekonanie polskiego rządu, aby nie podpisywał paktu z Moskwą, nim uczyni to Bukareszt, by nie osłabiać jego pozycji negocjacyjnej. W rozmowie między obu dyplomatami poruszono kwestię nacisków polskich na Rumunię. Beck zaprzeczył zarzutowi ponaglania Rumunów. Stwierdził, że gen. Gąsiorowski nie otrzymał od Piłsudskiego żadnych instrukcji odnośnie do uczynienia wobec Rumunów deklaracji dotyczącej paktu polsko-sowieckiego, a jego oświadczenie miało charakter przypadkowy. Przy tej okazji Beck wskazał na trudności, jakie spowodowała opieszałość Rumunów w kwestii paktu z Sowietami, która, jego zdaniem, wynikała z ich przekonania, iż Francja nie zamierza podpisywać paktu z ZSRR. Polski minister poinformował Laroche’a, że Warszawa nie podjęła jeszcze decyzji o ostatecznym terminie podpisania swego paktu z ZSRR i obiecał nie wywierać szczególnych nacisków na nowy rząd rumuński, aby dać mu czas na dojście do porozumienia z Moskwą ${ }^{21}$.

Francuzi starali się oddziaływać nie tylko na Polskę. W depeszy wysłanej do ambasadora francuskiego w Bukareszcie, Gabriela Puaux, sekretarz generalny Quai d'Orsay Alexis Léger stwierdzał, iż pożądane jest, aby Polacy powstrzymywali się od presji na Bukareszt, ale konieczne jest też, by rząd rumuński zdał sobie sprawę $\mathrm{z}$ braku korzyści utrzymywania negocjacji z ZSRR w martwym punkcie. Przedłużanie tej sytuacji stawia polski rząd, zdaniem Legera, w fałszywym położeniu względem Moskwy, dlatego nieodzowne byłoby, żeby Rumunia zaznaczyła swoje pragnienie sfinalizowania pertraktacji i szukała „lojalnie formuły porozumienia”. Z Paryża deklarowano, podobnie jak wcześniej z Warszawy, gotowość w ułatwieniu poszukiwań tej formuły 22 .

Zapewne 20 czerwca doszło do spotkania Zaleskiego z Titulescu w Genewie. Obaj dyplomaci przyjęli wówczas tekst projektu paktu rumuńsko-sowieckiego, który polski minister spraw zagranicznych miał przedstawić swemu sowieckiemu koledze. Charakterystyczne, że nie znalazła się w preambule „deklaracja Patka” ani też formuła na niej oparta, o której wcześniej wspominali Szembek i Gafencu jako zaakceptowanej przez Titulescu. Jak się okazało, Rumuni nie zdołali uzgodnić ostatecznej wersji projektu paktu, który miał być przedstawiony Rosjanom. Należy przypuszczać, że Titulescu wycofał się ze swojej wcześniejszej obietnicy, odrzucając propozycję własnego Ministerstwa Spraw Zagranicznych, a szkic paktu przed-

T. Sandu, Système de sécurité français en Europe centre-orientale. L'exemple roumain 1919-1933, Paris-Montréal 1999, s. 394.

21 Memorandum Gafencu z 11 VI 1932, AMAE. 71/1920-1944, U.R.S.S. Vol. 68, k. 149-151; memorandum Gafencu z 17 VI 1932, Behind..., s. 117-118; M. Wołos, op. cit., s. 575-576; M. Gmurczyk-Wrońska, Negocjacje polsko-sowieckie o pakt o nieagresji w roku 1927 i w latach 1931-1932, „Dzieje Najnowsze” 2012, nr 3, s. 46.

22 Pismo Légera do Puaux z 16 VI 1932, La Grande Roumanie alliée..., s. 230-231 (stąd cytat); memorandum Filality'ego z 18 VI 1932, Behind..., s. 19; T. Sandu, op. cit., s. 394; A. Skrzypek, Polsko-radziecki pakt o nieagresji z 1932 r., ZDSPR, 1976, t. XIII, s. 27. 
stawiony 23 czerwca Litwinowowi, prawdopodobnie z braku innego rozwiązania, wzorowany był na polsko-sowieckim układzie o nieagresji. W projekcie rumuńskim $\mathrm{w}$ artykule I znalazł się passus proponowany już przez Zaleskiego Litwinowowi w Berlinie 24 maja, mówiący o nieagresji „na terytoria, które znajdują obecnie pod władzą jednego albo drugiego z państw”. Szef NKID, zapowiadając uważne przestudiowanie dokumentu, zwrócił od razu uwagę na brak w nim jakiejkolwiek wzmianki o kwestiach spornych. Stwierdzając, iż jest on nie do przyjęcia dla ZSRR, zapytał Zaleskiego, czy nie trzeba byłoby powrócić do sprawy podpisania paktu polsko-sowieckiego, jeśli Rumunia będzie się upierać przy niewspominaniu tych spraw. Szef polskiej dyplomacji zbył milczeniem to pytanie, co pozwoliło Litwinowowi wywnioskować, że taką możliwość przewiduje ${ }^{23}$. Należy przypuszczać, że Zaleski, już po rozmowie z Titulescu, przestał być optymistą w sprawie możliwości zawarcia paktu rumuńsko-sowieckiego.

W oczekiwaniu na odpowiedź sowiecką dyplomaci rumuńscy podjęli wobec Polaków sondaże odnośnie do perspektyw podpisania przez RP paktu z ZSRR w kontekście możliwych negocjacji rumuńsko-sowieckich. 28 czerwca Gafencu indagował Szembeka w sprawie postępowania rządu RP w przypadku udaremnienia przez Litwinowa porozumienia rumuńsko-radzieckiego. Poseł RP odpowiedział kategorycznie, że Warszawa zobowiązana jest do podpisania paktu i nie będzie mogła dłużej tego odkładać. Rumuński podsekretarz stanu skonstatował wówczas, iż w ten sposób bezpieczeństwo wschodniej granicy obu państw oraz wartość ich przymierza zostały uzależnione od dobrej lub złej woli Litwinowa. Jeśli bowiem nie zgodzi się on na układ z Bukaresztem, to wówczas Polska podpisze oddzielne porozumienie z Moskwą, Rumunia pozostanie zawieszona w powietrzu, a wspólny polsko-rumuński front ulegnie rozbiciu. Gafencu uważał, iż narkom zna zamiary Warszawy w tej sprawie i „byłby imbecylem”, chcąc ułatwić zawarcie paktu sowiecko-rumuńskiego. W opinii rumuńskiego wiceministra realizacja przez Polskę jej zamiaru oznaczałaby pozbawienie przymierza ,jakiejkolwiek prawdziwej politycznej wartości w naszych oczach i w oczach naszych przyjaciół i przeciwników"24.

Kilka dni później, 3 lipca poseł Cădere został przyjęty na audiencji przez marszałka Piłsudskiego. W imieniu rządu rumuńskiego złożył on oświadczenie o gotowości zawarcia paktu z ZSRR, jednocześnie prosząc o odłożenie podpisania przez Warszawę własnego paktu do czasu finalizacji rozmów rumuńsko-sowieckich. Podobnie jak Gafencu, poseł wskazywał, iż niespełnienie tej prośby zwiekszyłoby swobodę manewru Litwinowa w negocjacjach o pakt z Rumunią, a także osłabiłoby alians Warszawy i Bukaresztu, szczególnie w wymiarze moralnym, w oczach rumuńskiej

23 Traktat o nieagresji między Rumunią a ZSRR. Genewa 20 VI 1932, AAN. Delegacja RP, T. 134, k. 44-46; telegram Litwinowa do LKSZ z 23 VI 1932, DVP, t. XV, s. 380 (stąd cytat); telegram Gafencu do Cădere z 6 VII 1932, Behind..., s. 125-126; A. Skrzypek, Zagadnienia rumuńskie..., s. 192; M. I. Mel'tûhov, Bessarabskij vopros meždu mirovymi vojnami 1917-1940, Moskva 2010, s. 160; G. Gafencu, op. cit., s. 305.

24 Telegram Gafencu do Titulescu z 28 VI 1932, Behind..., s. 119-120; por. A. Sheviakov, op. cit., s. $34-35$. 
i europejskiej opinii publicznej. Piłsudski pozytywnie przyjął oświadcznie rządu rumuńskiego; stwierdził jednak, iż ze względu na państwa bałtyckie, które już podpisały swoje pakty, a z którymi z powodu Rumunii Polska straciła możliwość jednoczesnego podpisania swojego układu, zbytnie odraczanie nie jest możliwe. Marszałek podkreślał znaczenie współdziałania z państwami bałtyckimi; podnosił ich niełatwe położenie względem Moskwy, odporność na jej presję oraz pełną solidarność z Polską. Marszałek przewidywał, iż ZSRR ze względu na trudną sytuację wewnętrzną oraz pogarszające się stosunki z Niemcami i wzrost napięcia na Dalekim Wschodzie będzie skłonny do podpisania paktu z Rumunią, z czego i ona powinna skorzystać. Piłsudski oczekiwał od Rumunów wprowadzenia jako podstawy negocjacji formuły streszczającej się w stwierdzeniu, iż podpisany układ nie przyniesie „ani korzyści, ani szkody dla obecnego stanu rzeczy” obu państw; była to zmodyfikowana wersja „deklaracji Patka”. Marszałek poinformował Cădere, że Polska nie będzie przyśpieszała podpisania układu z ZSRR, które jest planowane w Moskwie po powrocie Litwinowa z Genewy. Data powrotu uzależniona była od zawieszenia prac Konferencji Rozbrojeniowej i trudno było ją określić. Piłsudski jednak stwierdził, iż jeśli do tego czasu dyplomacja królewska nie byłaby w stanie sfinalizować swoich negocjacji z ZSRR, to perspektywa taka otwierałaby się w okresie późniejszym poprzez zwlekanie przez Polskę z ratyfikacją paktu ze Związkiem Sowieckim. Z rozmowy z marszałkiem poseł rumuński wywnioskował, iż jego nastawienie $\mathrm{w}$ sprawie podpisania paktu polsko-sowieckiego nie uległo zmianie, niemniej jednak dzięki zaistniałym okolicznościom Rumunia, zdaniem Cădere, uzyskała „dostateczny czas, aby osiągnąć definitywne podpisanie [swojego] paktu o nieagresji” z Sowietami. Stanowisko Piłsudskiego ocenił Gafencu za względnie zadowalające, jednakże miarodajne w tej kwestii było nastawienie Titulescu ${ }^{25}$.

Wspomniany dyplomata 5 lipca indagował Zaleskiego w Lozannie w sprawie odpowiedzi Litwinowa na złożoną 23 czerwca propozycję. Gdy otrzymał informację o braku odzewu ze strony szefa NKID, wyraził zaskoczenie, że w ciągu $15 \mathrm{dni}$ Zaleski nie poinformował go o stanie rozmów. Wówczas szef polskiej dyplomacji zakomunikował, iż w czasie wcześniejszych rozmów z Litwinowem domagał się wyszczególnienia w pakcie rumuńsko-sowieckim nieprzesądzania zagadnień między obu państwami, które są nadal otwarte. Titulescu skonstatował wówczas, iż Rosjanie nie ustąpili „ani na jotę” ze stanowiska, które zajmowali w Rydze i zarzucił szefowi polskiego MSZ, że Warszawa gotowa jest podpisać z Rosjanami układ o nieagresji, mimo żądania przez nich wzmiankowania w pakcie rumuńsko-sowieckim sporu o Besarabię oraz obowiązywania przymierza z Rumunią, w którym RP zobowiązała się zbrojnie bronić integralności Królestwa. W przekonaniu Titulescu Polska zniweczyła w ten sposób szanse porozumienia Bukaresztu z Moskwą i jest odpowiedzialna za zaistniałą sytuację. Polski minister polemizował z tym stwier-

25 Pismo Cădere do Vaida-Voevoda z 3 VII 1932, Behind..., s. 121-123; telegramy Schaetzela do poselstwa w Bukareszcie z 3 (nr 74) i 26 VII (nr 93) 1932, HIA. Rumunia. Ks. szyf., nr 6, p. 2, f. 3; Â. Kopanskij, I. Ė. Levit, op. cit., s. 97. 
dzeniem, deklarując, że Polska nie ratyfikuje swego układu z ZSRR, jeśli nie dojdzie do rumuńsko-sowieckiego porozumienia. Wówczas Titulescu jako kompensaty za podpisanie paktu zażądał oficjalnego zapewnienia, że ratyfikacja nigdy nie będzie mieć miejsca, jeżeli nie dojdzie do rosyjsko-rumuńskiego układu. Zaleski odpowiedział, że jest to jego intencją. Jednakże rzecz całą uzależnił od decyzji Piłsudskiego ${ }^{26}$.

Tymczasem Litwinow projekt paktu otrzymany od Zaleskiego przesłał do Moskwy, gdzie także uznano go za nie do przyjęcia. Sowieckie kierownictwo polityczne godziło się jednak na podjęcie rozmów z Titulescu. Przebywający w Szwajcarii szef NKID nie wykazywał jednak pośpiechu. Zdawał on sobie sprawę z zamiarów Polski podpisania paktu z ZSRR bez oglądania się na Rumunię i postanowił nie tylko wzmocnić te tendencje, ale i usztywnić własne stanowisko. Nie przekazał przeto Zaleskiemu, będącemu u niego 28 czerwca $\mathrm{z}$ wizytą, przygotowanego dla Rumunów kontrprojektu, lecz skrytykował Bukareszt za nieprzejednaną postawę, która, jego zdaniem, spowoduje przeciąganie negocjacji; wyraził też przekonanie, iż najszybszym sposobem na skłonienie Rumunii do pomyślnego zakończenia układów z Moskwą byłoby podpisanie paktu polsko-sowieckiego. Gospodarz Wierzbowej obiecał dać odpowiedź w ciągu kilku dni po skonsultowaniu się z marszałkiem Piłsudskim. 5 lipca doszło do kolejnego spotkania, w trakcie którego Zaleski poinformował narkoma o gotowości podpisania paktu przez Polskę, jednakże uprzedził, iż nie będzie on ratyfikowany, dopóki nie nastąpi sfinalizowanie układu z Rumunią. Po wstępnym zapoznaniu się z wręczonym przez Litwinowa kontrprojektem, polski minister zauważył, iż raczej nie zostanie on zaakceptowany przez Bukareszt $\mathrm{z}$ powodu wzmiankowania w nim terytorialnego sporu i nieobecności odniesienia do terytoriów znajdujących się pod władzą Rumunii. Litwinow odpowiedział, że adnotację o sporze oraz brak zgody ZSRR na uznanie przynależności Besarabii do Rumunii uważa za zasadnicze warunki negocjacji i jeśli zostaną one przyjęte przez Bukareszt, to otwiera to pole dla „najdalej idących uzgodnień” w rozmowach z Titulescu ${ }^{27}$.

Titulescu w korespondencji z premierem i własnym ministerstwem spraw zagranicznych odniósł się negatywnie do propozycji sowieckiej, przytaczając na wzmocnienie swego stanowiska list Zaleskiego $\mathrm{z}$ zawartymi w nim zastrzeżeniami podnoszonymi w rozmowie z Litwinowem. Szef delegacji rumuńskiej przy Lidze Narodów ostrzegał Bukareszt przed podpisaniem paktu z ZSRR, z umieszczoną

26 Telegram Titulescu do MSZ z 5 VII 1932, Behind..., s. 124-125; A.-M. Mironov, op. cit., s. 114-115; E. Bold, R. O. Locovei, Relaţii româno-sovietice (1918-1941), Iaşi 2008, s. 140; L. Pădureac, Relaţiile româno-sovietice 1917-1934, Chişinău 2003, s. 81; zob. telegram Gafencu do Cădere z 6 VII 1932, Behind..., s. 125-126.

27 Decyzja Biura Politycznego o pakcie z Rumunią z 28 VI 1932, O. Ken, A. Rupasov, Politbro CK VKP(b) i otnošeniâ SSSR s zapadnymi sosednimi gosudarstvami (konec 1920-1930-h gg.). Problemy, dokumenty, opyt kommentaria, Č. 1 [Dekabr' 1928 - in' 1934 g.], Sankt Petersburg 2000, s. 325-330, telegram Krestinskiego do Litwinowa z 28 VI 1932, DVP, t. XV, s. 392; telegram Litwinowa z Genewy do LKSZ z 30 VI 1932, DVP, t. XV, s. 392; telegram Litwinowa z Genewy do LKSZ z 5 VII 1932 wraz z załączonym projektem paktu o nieagresji między ZSRR i Rumunią, Sovetsko-rumynskie otnošeniâ 1917-1941. Dokumenty i materialy, t. 1, 1917-1934, red. A. A. Avdeev i in., Moskva 2000 (dalej: SRO), s. 373-376; A. Skrzypek, Zagadnienia rumuńskie..., s. 192. 
w nim wzmianką o sporze besarabskim, nawet jeśli rezultatem byłoby odtworzenie rozbitego - jego zdaniem - wspólnego frontu polsko-rumuńskiego, ponieważ sprawa rozstrzygnięcia sporu „wisiałaby nad krajem jak straszny miecz Damoklesa” i prędzej czy później musiałaby nabrać aktualności. Titulescu w dalszym ciągu był zdania, że należy „z godnością i (...) bez błagania” podnosić wobec Polski poważne konsekwencje, jakie nieuchronnie wynikną dla przymierza obu państw, po podpisaniu przez nią paktu z ZSRR. Zalecał także, aby władze rumuńskie podkreślały wobec własnej opinii publicznej, że alians z Polską pozostaje w mocy i że pakt Brianda-Kellogga, którego sygnatariuszem są także Sowiety, jest lepszy dla interesów kraju niż pakt z nimi, niosący za sobą zgodę na warunek szkodzący fundamentalnym interesom Rumunii ${ }^{28}$.

Odrzucając pakt z Moskwą, rumuński polityk nie zaniechał demonstrowania wobec Francuzów, którym znowu zaczęło zależeć na doprowadzeniu do finalizacji układu rumuńsko-sowieckiego, iż on także dąży do jego zawarcia pod warunkiem niewzmiankowania sporu besarabskiego. W efekcie Francuzi zobowiązali się oddziaływać w tym kierunku na dyplomatów polskich i sowieckich. Po rozmowie 8 lipca z premierem Herriotem Zaleski zadeklarował następnego dnia wobec Titulescu, iż będzie przekonywał narkoma do porzucenia stawianych wobec Bukaresztu żądań. Namawiał też rumuńskiego polityka do osobistego spotkania z szefem NKID. Titulescu ze sceptycyzmem odniósł się do możliwości odstąpienia przez Litwinowa od jego żądań. Szef polskiej dyplomacji przypomniał wówczas swoje oświadczenie uczynione wobec ludowego komisarza, w którym stwierdził, że Polska nigdy nie będzie ratyfikować swojego paktu z Moskwą bez wcześniejszego zawarcia układu rumuńsko-sowieckiego. Nie przekonało to Titulescu, który nie wykluczał, iż Zaleskiemu zależy na tym spotkaniu, aby później w wypadku fiaska mógł oświadczyć, że zrobił wszystko co możliwe dla doprowadzenia do porozumienia rumuńsko-sowieckiego i uzasadnić moralnie podpisanie przez RP paktu z Moskwą za plecami Bukaresztu. Z drugiej strony odmowa zobaczenia się z Litwinowem mogła, zdaniem Rumuna, stanowić dla Zaleskiego powód do obwiniania Bukaresztu, iż nawet nie próbował dyskutować z Rosjanami i przez to ponosi odpowiedzialność za zaistniałą sytuację. W tych okolicznościach Titulescu wyraził zgodę na spotkanie z szefem NKID, warunkując to oficjalnym powtórzeniem przez Zaleskiego w obecności obu interlokutorów deklaracji, iż Polska nie ratyfikuje paktu z ZSRR, jeśli nie zostanie osiągnięte porozumienie z Rumunią. Gospodarz Wierzbowej przystał na tę propozycję - jak się wydaje na własną odpowiedzialność - nie posiadając w tej sprawie upoważnienia Piłsudskiego. Aby jednak uniknąć sytuacji, w której do ratyfikacji paktu polsko-sowieckiego mogłoby nie dojść na skutek złej woli Rumunii, Zaleski zmodyfikował swoje oświadczenie, które teraz stwierdzało, iż Polska nie ratyfikuje paktu z Sowietami, o ile te będą żądać, żeby Rumunia uznała, iż Besarabia jest spornym terytorium. Niebawem Titulescu wycofał się ze swojej zgody na spotkanie z Litwinowem. Uznał, że wykorzystanie deklaracji Zaleskiego

28 Telegram Titulescu do MSZ z 7 VII 1932, Behind..., s. 127-130; A.-M. Mironov, op. cit., s. 117. 
w bezpośrednich rozmowach $\mathrm{z}$ narkomem mogłoby mu je utrudnić, a polaryzacja stanowisk wręcz doprowadzić do zerwania negocjacji. Ze względu na rozpatrywaną możliwość przełożenia ich na jesień, przedstawiciel Rumunii przy Lidze Narodów skonstatował, iż aby uniknąć sytuacji nieodwracalnej, Polacy i Francuzi powinni nadal przygotowywać grunt dla pertraktacji rumuńsko-sowieckich ${ }^{29}$.

10 lipca 1932 r. z polecenia Herriota spotkał się z Litwinowem Massigli - członek delegacji francuskiej na Konferencję Genewską - w celu wyjaśnienia możliwości usunięcia rozbieżności pomiędzy Rumunią a ZSRR. Massigli wskazywał, iż Titulescu sprzeciwia się dwu sformułowaniom zawartym we wręczonym Zaleskiemu 5 lipca sowieckim projekcie paktu. Były to wzmianki o terytorialnym sporze umieszczone $\mathrm{w}$ preambule i artykule $\mathrm{I}^{30}$. Litwinow odpowiedział, iż treść zawarta w preambule stanowi wyjście naprzeciw „deklaracji Patka”, którą Zaleski przedstawił mu w Berlinie w maju tego roku. Szef NKID gotów był wyeliminować wzmiankę o sporze z artykułu I, pod warunkiem, iż nie zostanie ona niczym zastąpiona, a na artykuł I będzie się składał jedynie tekst uzgodniony w Rydze między Sturdzą a Stomoniakowem. Massigli uznał propozycję dotyczącą artykułu I za wartą rozważenia, natomiast odnośnie do preambuły zamierzał szukać innej formuły. 14 lipca odwiedził Litwinowa Zaleski. Powołując się na ustalenia z Titulescu i Massiglim, wystąpił z propozycją wyłączenia z paktu wszelkich wzmianek o spornych kwestiach, a wprowadzenia w protokole dodatkowym stwierdzenia, że „obecny układ zawierający wzajemne zobowiązanie nieagresji przeciwko terytoriom znajdującym się w chwili podpisania pod władzą jednej albo drugiej umawiającej się strony, nie może być wykorzystany dla innych celów, w szczególności..." W miejsce wielokropka - zdaniem szefa NKID - należało wprowadzić „rozwiązanie kwestii spornych”. Litwinow odpowiedział, iż ZSRR nie mógłby uznać władzy Rumunii nad Besarabią, gdyż byłoby to pośrednim zaakceptowaniem przezeń zaboru tej prowincji. Natomiast wyraził gotowość przyjęcia każdej formuły o nieagresji względem Besarabii. Uważał też, iż w pakcie należy wspomnieć otwarcie o pozostałych sprawach spornych. Pod tymi warunkami Litwinow skłonny był spotkać się z Titulescu i negocjować treść protokołu końcowego. 16 lipca doszło do kolejnego spotkania Massigliego z szefem NKID. Dyplomata francuski zasugerował wówczas, iż Titulescu gotów byłby wyrzec się sformułowania o "agresji na terytorium znadującym się pod władzą", pod warunkiem niewprowadzania wzmianki o „spornych kwestiach” oraz wspomnienia jedynie w protokole końcowym, iż pakt nie może być „wykorzystywany do jakichś innych

29 Telegramy Titulescu do MSZ z 7 VII, 9 VII 1932, Behind..., s. 126-127, 131-133; telegram Vaida-Voevoda do Titulescu z 14 VII 1932, SRO, s. 377-378; telegram Titulescu do Vaida-Voevoda z 17 VII 1932, ibidem, s. 380-381; telegram Schaetzela do poselstwa w Bukareszcie z 26 VII 1932, nr 93, HIA. Rumunia. Ks. szyf., nr 6, p. 2, f. 3.

30 [Preambuła] CKW ZSRR z jednej strony i J. K. M. Król Rumunii z drugiej strony (...) „konstatując, że zawarcie obecnego paktu nie przyniesie żadnego uszczerbku pozycji każdej ze Stron w sporach terytorialnych i innych istniejących między nimi i że te spory pozostają na boku i w żadnym stopniu nie będą poruszone przez niniejszy pakt [podkr. HW], zdecydowali zawrzeć niniejszy pakt (...)". 
celów". Litwinow nie zgodził się na te propozycje, mimo sugestii Massigliego, iż w zamian Herrot mógłby doprowadzić do finalizacji paktu francusko-sowieckiego ${ }^{31}$.

Tymczasem rząd rumuński nie rezygnował z zabiegów uzyskania od Warszawy odłożenia podpisania paktu z Rosją, jednocześnie starając się otrzymać formalne potwierdzenie deklaracji Zaleskiego i enuncjacji Piłsudskiego, rozumianych jako zobowiązanie Polski do nieratyfikowania paktu z ZSRR przed dojściem do skutku układu rumuńsko-sowieckiego. Rumuni odrzucali umieszczenie w pakcie z ZSRR jakiegokolwiek stwierdzenia sugerującego istnienie sporu o Besarabię. Rząd w Bukareszcie gotów był przystać na deklarację Patka, o której wspominał marszałek Piłsudski („pakt nie zmieni w czymkolwiek obecnej sytuacji dwóch umawiających się stron"). Nie uzgodniono jednak ostatecznej formuły ze względu na - jak można się domyślać - opozycję Titulescu. Ujawnił się wówczas dysonans między stanowiskiem Wierzbowej a deklaracją Zaleskiego złożoną Titulescu 9 lipca. Cădere po rozmowie z Beckiem zauważył, iż nie traktuje on oświadczenia Zaleskiego (warunkującego ratyfikację przez Polskę paktu z Moskwą, uprzednią finalizacją paktu rumuńsko-sowieckiego) ,,jako absolutnego zobowiązania” RP wobec Rumunii, ale jako ,jedynie czynnik nacisku na Sowiety i jako środek zyskania na czasie dla zawarcia paktu sowiecko-rumuńskiego". Poseł rumuński stwierdził wówczas, iż dojście do skutku tego układu z ewentualnym wprowadzeniem do jego treści klauzuli o sporze terytorialnym będzie bezpośrednim naruszeniem przymierza między Warszawą a Bukaresztem opierającego się m.in. na gwarantowaniu integralności terytoriów obu sygnatariuszy. Beck bronił się, twierdząc, iż przymierze nie ulegnie osłabieniu i że w polsko-sowieckim pakcie nienaruszalność wcześniejszych traktatów została zagwarantowana. Wiceminister zapewniał, iż Polska podejmie każdy wysiłek, aby przekonać Rosjan do zawarcia paktu. W związku z tym poinformował on o wyjeździe do Genewy naczelnika Wydziału Wschodniego - Tadeusza Schaetzela - mającego zastąpić w rozmowach z Litwinowem Zaleskiego, który udał się 14 lipca na leczenie do Karlovych Varów. Na rzecz porozumienia sowiecko-rumuńskiego miał także pracować w Moskwie poseł Patek, który otrzymał w tej sprawie odpowiednie instrukcje ${ }^{32}$.

\section{Artykuł I}

Za akt, sprzeczny z zobowiązaniem ustalonym w poprzednim akapicie, będzie uważany każdy akt przemocy, skierowany przeciwko całości i nietykalności terytorium czy też politycznej niezależności drugiej Umawiającej się Strony, podobnie, jak [i] każda próba rozwiązania siłą terytorialnych albo innych sporów między obu Umawiającymi się Stronami [podkr. HW], nawet jeśli podobne akty będą popełnione bez wypowiedzenia wojny i wszelkich możliwych jej następstw. Załącznik do telegramu Litwinowa z Genewy do LKSZ z 5 VII 1932, SRO, s. 373-374.

31 Telegramy Litwinowa z Genewy do LKSZ z 10 i 16 VII 1932, ibidem, s. 376-377, 379; telegram Litwinowa do LKSZ z 14 VII 1932 r. DVP, t. XV, s. 405-406; M. Wołos, op. cit., s. 577; A.-M. Mironov, op. cit., s. 115; Â. Kopanskij, I. Ė. Levit, op. cit., s. 96.

32 Telegram Gafencu do Cădere z 6 VII 1932, Behind..., s. 125-126 (pierwszy cytat); telegram Cădere do MSZ z 16 VII 1932, ibidem, s. 133-134 (kolejne cytaty); pismo Cădere do MSZ z 21 VII 1932, ibidem, s. 136; instrukcja Gafencu do Cǎdere z 22 VII 1932, ibidem, s. 136-138; telegram Litwinowa do LKSZ z 14 VII 1932, DVP, t. XV, s. 406; telegram Puaux do Herriota z 22 VII 1932, Documents diplomatiques 
Schaetzel prowadził pertraktacje z Litwinowem zapewne pomiędzy 15 a 23 lipca. Szef NKID zgodził się na usunięcie z preambuły sformułowania, że „spory terytorialne i inne istniejące” między stronami pozostają „na boku” i w żadnym wypadku nie będą mieć wpływu na niniejszy traktat. Zrezygnował też w artykule I ze zdania o uznaniu za sprzeczną ze zobowiązaniem o nieagresji „każdą próbę rozwiązania siłą terytorialnych albo innych sporów między obu Umawiającymi się Stronami”. Domagał się natomiast wprowadzenia wyrażenia o nieprzesądzaniu rozstrzygnięcia istniejących sporów, chcąc w ten sposób pozostawić ślad pozostawania otwartą kwestii besarabskiej. Ustępstwa i propozycja Litwinowa nie znalazły uznania w oczach Titulescu. 22 lipca zaproponował on, przez Schaetzela, Rosjanom bez ujawniania swojego autorstwa podpisanie paktu o nieagresji, odmiennego niż dotąd zawierane, będącego powtórzeniem w wymiarze dwustronnym zobowiązań z paktu Brianda-Kellogga. Narkom odpowiedział, że ma instrukcje swego rządu jedynie odnośnie do podpisania układu o nieagresji „starego wzoru”. Nie odrzucając rumuńskiej propozycji, Litwinow trwał przy formule „istniejących sporów”. Ze względu na zbliżanie się podpisania paktu polsko-sowieckiego negocjacje zostały przerwane. Termin ich podjęcia na nowo wyznaczono na 21 września w Genewie, przy okazji wznowienia prac Sekretariatu Konferencji Rozbrojeniowej. Nie wykluczano, aby do tego czasu wykorzystać dla kontynuacji rozmów jakąś inną okazję ${ }^{33}$.

Ratyfikacja przez Związek Sowiecki paktów o nieagresji z Łotwą ${ }^{34}$ i Finlandią ${ }^{35}$ oraz zapowiedź rychłej ratyfikacji z Estonią ${ }^{36}$ postawiła na porządku dziennym sprawę podpisania układu polsko-sowieckiego. 21 lipca Beck poinformował Cădere o instrukcji udzielonej Patkowi podpisania 23 tego miesiąca paktu, bez czekania na powrót Litwinowa $z$ Genewy. Termin ten został jednak przesunięty na 25 lipca. Można sądzić, iż nastąpiło to pod wpływem próśb ze strony rządu rumuńskiego, który chciał mieć kilka dni na oswojenie z tym faktem własnej opinii publicznej. Obawiano się, iż zaskoczona nim mogłaby zwrócić się „zwartym frontem” przeciwko Polsce. Rumuńskie MSZ poinformowało zatem Wierzbową o przygotowywanym dla prasy oświadczeniu, w którym zwracano uwagę, że podpisanie przez RP układu z ZSRR nie powinno być interpretowane jako rozejście się dróg Warszawy

français 1932-1939, 1-ère serie (1932-1935), t. 1 (9 juillet-14 novembre 1932) (dalej: DDF, t. I), s. 81-82; telegram Szembeka do MSZ z 22 VII 1932, HIA. Rumunia. Ks. szyf., nr 6, p. 2, f. 3, zob. też telegram Schaetzela do poselstwa w Bukareszcie z 9 VII 1932, nr 79, ibidem; pismo Cădere do Becka z 20 VII 1932, Behind..., s. 135; F. Dessberg, La Roumanie et la Pologne dans la politique soviétique de la France: la difficulté détablir un «front uni» (1924-1935), „Revue Historique des Armées” 2006, nr 3 (244), s. 69.

33 Telegram Massigli do MSZ z 23 VII 1932 (nr 704-705). DDF t. I, s. 91 (stąd cytaty); telegram Szembeka do MSZ z 22 VII 1932, HIA. Rumunia. Ks. szyf., nr 6, p. 2, f. 3; projekt paktu autorstwa Titulescu przekazany przez Schaetzela Litwinowowi 22 VII 1932 r. DVP, t. XV, przyp. 206, s. 785-786; telegram Titulescu do MSZ z 24 VII 1932, SRO, s. 381-387; pismo Cădere do Vaida-Voevoda z 25 VII 1932, Behind..., s. 141-145; L. Pădureac, op. cit., s. 83; J. Beck, Ostatni raport, przedmową poprzedził M. Wojciechowski, Warszawa 1987, s. 33.

34 Ratyfikacja przez ZSRR nastąpiła 11 lipca 1932 r., przez Finlandię - 7 lipca 1932 r.

35 Ratyfikacja przez ZSRR nastąpiła 11 lipca 1932 r., Łotwa uczyniła to 21 lipca 1932 r.

36 Ratyfikacja przez ZSRR nastąpiła 5 sierpnia 1932 r., przez Estonię - 3 sierpnia 1932 r. 
i Bukaresztu, ponieważ Polska dała Rumunii oficjalne zapewnienie o nieratyfikowaniu paktu z Sowietami przed podpisaniem porozumienia o nieagresji miedzy Moskwą a Bukaresztem. Jednocześnie deklarowano, że Rumunia, mimo sygnowania wspólnie z ZSRR paktu Brianda-Kellogga o wyrzeczeniu się wojny, pragnie zawrzeć z tym państwem pakt o nieagresji zbliżony charakterem do polsko-sowieckiego, pod warunkiem poszanowania swoich słusznych interesów ${ }^{37}$.

Ze stanowiskiem rządu rumuńskiego nie identyfikował się Titulescu, mimo że instrukcja przesłana Cădere była według Gafencu z nim uzgodniona. Jak już wspomniano, optował on za formułą paktu rumuńsko-sowieckiego analogiczną do układu paryskiego z 28 sierpnia 1928 roku. Krytykował Palatul Sturdza za nieprawdziwe informowanie własnej i międzynarodowej opinii publicznej o pełnym porozumieniu z Polską w sprawie negocjacji o pakt o nieagresji oraz za brak w oficjalnych enuncjacjach akcentów krytycznych pod jej adresem. Zdaniem Titulescu taki obraz sprawiał, iż trudno było nawet państwu życzliwemu wobec Rumunii, którego władze miały informacje na temat rzeczywistego stanu rzeczy odnośnie do rokowań z ZSRR, zrobić coś dla niej, bez poparcia błędnie informowanego własnego społeczeństwa ${ }^{38}$.

Treść rumuńskiego komunikatu zawierającego stwierdzenie o uzależnieniu ratyfikacji przez Polskę paktu z ZSRR od podpisania sowiecko-rumuńskiego układu o nieagresji, wywołała zastrzeżenia w Warszawie. 25 lipca Beck w rozmowie z Cădere stwierdził, iż oświadczenie rumuńskie postawiło rząd RP w bardzo delikatnej sytuacji, gdyż nie odpowiada ono ani jego zaangażowaniu w sprawę, ani intencjom. Wiceszef polskiej dyplomacji zaprzeczył złożeniu przez Zaleskiego zapewnienia zamieszczonego $\mathrm{w}$ komunikacie rumuńskim. Jeszcze tego samego dnia poinformował on Szembeka, iż „publikacja tego rodzaju dowolnych interpretacji naraża rząd rumuński na ewentualność dementi” z polskiej strony. Poseł RP w Bukareszcie otrzymał polecenie przekazania miejscowej prasie, iż Polska, która parafowała swój pakt w styczniu br., odkładając ze względu na Rumunię jego podpisanie do teraz, nie zamierza na razie go ratyfikować, albowiem nadal nie zostały zakończone negocjacje rumuńsko-sowieckie. Szembek miał wyrazić przeświadczenie, że przy ogólnym wysiłku i dobrej woli dojdzie do ich finalizacjii ${ }^{39}$. Można sądzić, iż pryncypialny sprzeciw Warszawy odnośnie do uzależniania ratyfikacji własnego paktu od dojścia do skutku układu Moskwy i Bukaresztu, wynikał ze wzrastającego sceptycyzmu co do osiągnięcia sukcesu negocjacji sowiecko-rumuńskich oraz wagi,

37 Telegramy Becka do poselstwa w Bukareszcie z 15 VII (nr 85), 18 VII (nr 86) 1932, HIA. Rumunia. Ks. szyf., nr 6, p. 2, f. 3; telegram Cădere do Gafencu z 21 VII 1932, Behind..., s. 136; telegram Gafencu do Cădere z 22 VII 1932, ibidem, s. 136-138; Informacja dla prasy rumuńskiego MSZ z 25 VII 1932, ibidem, s. 140; Stanowisko Rumunii, „Gazeta Polska” 24 VII 1932, s. 1.

38 Telegram Titulescu do MSZ z 24 VII 1932, SRO, s. 381-387; E. Bold, R. O. Locovei, op. cit., s. 140-141; A.-M. Mironov, op. cit., s. 116.

39 Telegram Becka do poselstwa w Bukareszcie z 25 VII 1932, HIA. Rumunia. Ks. szyf., nr 6, p. 2, f. 3 (stąd cytat); pismo Cădere do premiera Vaida-Voevoda z 25 VII 1932, Behind..., s. 141-145; telegramy Schaetzela do poselstwa w Bukareszcie z 25 VII (nr 91 i 92), HIA. Rumunia. Ks. szyf., nr 6, p. 2, f. 3; telegram Szembeka do MSZ z 26 VII 1932, nr 83, ibidem; zob. telegram Becka od Szembeka z 24 VII 1932 r., nr 7, ibidem. Tel. osob. ks. 1; M. I. Mel'tûhov, op. cit., s. 160. 
jaką przywiązywano do zawarcia paktu polsko-sowieckiego, którego nie chciano przekreślać $\mathrm{w}$ ten sposób.

Rząd rumuński powodowany stanowiskiem własnej opinii publicznej, ostro krytykującej podpisanie przez Polskę paktu o nieagresji oraz obawiający się, by postawa RP w sprawie ratyfikacji nie osłabiła stanowiska Bukaresztu w negocjacjach z Sowietami, starał się doprowadzić do uznania przez Warszawę deklaracji Zaleskiego z 9 lipca za obowiązującą. Argumentowano m.in., że na polskim rządzie ciąży obowiązek zaangażowania się w negocjacje rumuńsko-sowieckie, ponieważ bez zapewnienia polskiego rządu, że kwestia Besarabii pozostanie „na boku”, nigdy nie doszłoby do ich podjęcia. W końcu 30 lipca oficjalnie oświadczył Schaetzelowi, że deklaracja Zaleskiego stwierdzająca, iż „Polska nie przystąpi do ratyfikacji paktu o nieagresji z Republiką Sowiecką”, o ile ta będzie podtrzymywać „swoje pretensje dotyczące terytorialnego sporu jest uważana przez królewski rząd Rumunii jako ostateczna i nieodwołalna”. W odpowiedzi Szef Wydziału Wschodniego nadal kwestionował fakt złożenia przez Zaleskiego wspomnianej deklaracji, zaznaczając konieczność wyjaśnienia sprawy. Wskazywał też na niewłaściwe sformułowanie zawarte w oświadczeniu Cădere („pretensje dotyczące terytorialnego sporu”). Przypominał, iż w prowadzonych z Litwinowem negocjacjach w Genewie początkowo obstawał on przy sformułowaniu „spory terytorialne i inne istniejące między umawiającym się krajami”. Jednak gotów był zastąpić słowa "spory terytorialne i inne” określeniem „różnice”. Nie była to formuła zadowalająca i dlatego pertraktacje nie zostały ukończone. Schaetzel, zdając sobie sprawę z intencji Rumunów, uważał, iż nie należy łączyć dyskutowanych sformułowań z ratyfikacją przez Warszawę paktu z Sowietami. Szef Wydziału Wschodniego poinformował Cădere o negatywnym nastawieniu Piłsudskiego odnośnie do deklaracji o nieratyfikowaniu przez Polskę paktu bez Rumunii, jednocześnie podkreślając wagę, jaką Warszawa przywiązuje do przymierza obu państw oraz jej gotowość „przyczynienia się wszelkimi sposobami" do zawarcia paktu rumuńsko-sowieckiego ${ }^{40}$.

Rumuni nie rezygnowali z uzyskania od Polski takiej deklaracji. 3 sierpnia w tej sprawie spotkał się poseł Cesianu z premierem Herriotem i starał się go przekonać do podjęcia interwencji. Szef rządu francuskiego obiecał rozmówić się z ambasadorem RP we Francji Alfredem Chłapowskim, jednocześnie podając w wątpliwość skuteczność tych zabiegów ze względu na przewidywany upór marszałka Piłsudskiego

40 Pismo Gafencu do Cǎdere z 25 VII 1932, Behind..., s. 140-141; pismo Cǎdere do premiera Vaida-Voevoda z 25 VII 1932, ibidem, s. 141-143 (stąd pierwszy cytat); telegram Szembeka do MSZ z 25 VII 1932 r., nr 2; HIA. Rumunia. Tel. osob. ks. 1; nota rządu rumuńskiego złożona 30 VII na ręce Schaetzela przez Cǎdere (stąd drugi i trzeci cytat), Behind..., s. 145; telegramy Schaetzela do poselstwa w Bukareszcie z 26 VII (nr 93) 31 VII (nr 96- stąd czwarty, piąty i szósty cytat) 1932, HIA. Rumunia. Ks. szyf., nr 6, p. 2, f. 3; telegram Szembeka do MSZ z 30 VII 1932, nr 86, ibidem; telegramy Puaux do Herriota z 26 VII (nr 295), 27 VII (nr 296-298) 1932, DDF, t. I, s. 102, 103-104; raporty prasowe Szembeka za 1-18 i 19-30 VIII 1932, AAN. Ambasada w Bukareszcie, t. 343, k. 159-161, 169-170; raport ppłk. Michałowskiego do Szefa Sztabu Głównego WP z 19 VIII 1932, S. Łopatniuk, Nieznane dokumenty archiwalne $z$ historii polsko-radzieckich rokowań o pakt o nieagresji, ZDSPR, 1969, t. V, s. 190-193; G. Gafencu, op. cit., s. 305; zob. A. Sheviakov, op. cit., s. 37. 
i płka Becka. Z drugiej strony zastanawiał się, jak długo polski rząd musiałby czekać z ratyfikacją swojego paktu z ZSRR, gdyby zgodził się z życzeniem Rumunów. Herriot, odżegnując się od wywierania nacisku, doradzał Bukaresztowi podpisanie z Moskwą paktu o nieagresji bez nadmiernego przewlekania sprawy, szczególnie, że Polska i kraje bałtyckie sfinalizowały już swoje układy. Francuz obiecał Rumunom pośrednictwo w kontaktach z Rosjanami i poszukiwanie zadowalającej ich formuły. Cesianu zapytał też, czy Francja zawrze pakt z Sowietami, jeśli Rumunia nie podejmie z nimi negocjacji. Herriot odpowiedział, że pomimo ponagleń ze strony Rosjan w sprawie podpisania układu, Paryż zdecydowany jest czekać na sfinalizowanie paktu przez Rumunów. O tym, jak długo mogłoby to trwać, miał zdecydować rząd francuski po gruntownym przestudiowaniu sprawy zawarcia paktu o nieagresji z ZSRR ${ }^{41}$.

Jeszcze tego samego dnia Herriot nakazał francuskiemu chargé d'affaires w Warszawie Pierre Bressy’emu (ambasador Laroche był wówczas na urlopie) przekazanie na Wierzbową démarche, w której polecił podkreślić wagę odroczenia ratyfikacji paktu polsko-sowieckiego, dopóki pertraktacje rumuńsko-sowieckie o pakt nieagresji nie zostałyby sfinalizowane. W wypadku przyśpieszenia ratyfikacji przez Polskę nie tylko uległaby osłabieniu pozycja przetargowa Rumunów wobec Rosjan, ale też mogłoby dojść do zerwania rozmów i pozostawienia Bukaresztu poza tworzącym się system układów o nieagresji na zachodniej granicy ZSRR. Musiałoby to zdaniem francuskiego premiera doprowadzić do nadania przez Moskwę aktualności sprawie przynależności Besarabii oraz stanowić świadectwo rozluźnienia więzów łączących Polskę i Rumunię. Herriot liczył, iż odbiorcą démarche będzie minister Zaleski, który wydawał mu się osobą przywiązującą większą wagę do solidarności polsko-rumuńskiej niż do jednoczesnego wprowadzenia w życie paktów Polski i państw bałtyckich. Tymczasem Minister Zaleski przebywał na urlopie zdrowotnym i Bessy spotkał się najpierw 5 sierpnia z naczelnikiem Wydziału Wschodniego Schaetzelem, a następnie 10 tego miesiąca $\mathrm{z}$ wiceministrem Beckiem (wcześniej był on nieobecny w Warszawie). W trakcie spotkania 5 sierpnia naczelnik Wydziału Wschodniego stwierdził, iż rząd RP niejednokrotnie dawał Rosjanom i Rumunom jasne komunikaty, że może on zawiesić na pewien okres ratyfikację swojego paktu z ZSRR, aby dać możliwość doprowadzenia do końca negocjacji sowiecko-rumuńskich. W opinii Schaetzela istniała możliwość wypracowania kompromisu między obu stronami. Świadczyła o tym ustępliwość Litwinowa, który mając na myśli kwestię besarabską, początkowo upierał się przy umieszczeniu w pakcie wzmianki o „terytorialnym sporze”, następnie zgodził na szerszą formułę o „sporach terytorialnych i innych", aby zaakceptować wprowadzenie wzmianki o „zatargach istniejących” między obu państwami. Naczelnik Wydziału Wschodniego deklarował wolę współpracy w osiągnięciu tego kompromisu. Wskazywał jednak również, iż dużą cześć winy za niedojście paktu do skutku ponosili sami Rumuni. Dlatego też Polska nie mogła uzależniać ratyfikacji swojego układu o nieagresji od sukcesu negocjacji

41 Telegram Cesianu do MSZ w Bukareszcie z 3 VIII 1932, Behind..., s. 146-148; T. Sandu, op. cit., s. 403; F. Dessberg, op. cit., s. 70. 
rumuńsko-sowieckich, aby nieprzewidziane opóźnienia lub ich zerwanie nie przekreśliły jej porozumienia z ZSRR. Naczelnik Wydziału Wschodniego zwracał też uwagę, iż pakt polsko-sowiecki jest elementem solidarności postępowania Warszawy i państw bałtyckich wobec Moskwy. Jego niesfinalizowanie mogłoby zostać wykorzystane przez Rosjan do zerwania więzi tych krajów z Polską. Schaetzel akcentował również wagę polsko-sowieckiego paktu o nieagresji jako asekuracji granicy wschodniej RP przy narastającej w Niemczech fali rewizjonizmu oraz jako czynnika rozluźniającego groźną dla Polski współpracę sowiecko-niemiecką.

Przebieg rozmowy Bressy’ego z Beckiem miał z grubsza podobny przebieg. Wiceminister spraw zagranicznych bez ogródek zaznaczył, iż Warszawa nie ma pewności odnośnie do osiągnięcia przez Rumunów porozumienia z ZSRR i nie będzie w nieskończoność zawieszać jego wejście w życie. Konstatował też obecność w polityce rumuńskiej dwóch tendencji, z których jedna była wroga zawarciu paktu z Moskwą, a druga go nie wykluczała. Beck poinformował francuskiego dyplomatę, iż Polska zamierza czekać na powstanie nowego rządu rumuńskiego i na zajęcie przezeń jasnego stanowiska w sprawie paktu. Jeśli ten rząd wykazałby się zdecydowaniem i podjął rokowania z Moskwą wcześniej niż przewidywany wrześniowy termin, dyplomacja RP gotowa byłaby wystąpić z bons offices. Wiceminister zadeklarował również, iż rząd RP byłby gotów opóźnić ratyfikację swojego paktu, nawet nie bacząc na sowieckie nalegania, jeśli nastąpiłoby wznowienie negocjacji Moskwa-Bukareszt i pojawiłyby się widoki na osiągnięcie porozumienia ${ }^{42}$.

Herriot usiłował także oddziaływać na stanowisko Wierzbowej poprzez ambasadora Chłapowskiego. Do spotkania doszło 6 sierpnia. Zasadniczym tematem była kwestia ratyfikacji układu polsko-sowieckiego. Przy okazji francuski premier krytycznie odniósł się do polityki rumuńskiej, określając ją jako „niezręczną, dwoistą (...), mogącą wywołać w kierowniczych sferach polskich niezadowolenie i rozgoryczenie”. Podobnie jak Beck był on zwolennikiem możliwie szybkiego podjęcia rozmów rumuńsko-sowieckich, uznając termin wrześniowy proponowany przez Titulescu za zbyt odległy. Herriot poinformował Chłapowskiego o wywieraniu przez Rosjan, powołujących się na podpisanie paktu polsko-sowieckiego, silnego nacisku na Paryż w celu wznowienia przerwanych w roku ubiegłym rokowań francusko-radzieckich. Równolegle dyplomacja sowiecka przedsięwzięła też zabiegi na rzecz uniezależnienia paktu z Francją od zawarcia układu z Rumunią. W końcu lipca wydawały się one trafiać na podatny grunt. W trakcie rozmowy 2 sierpnia, Dowgalewskiemu udało się nawet „wyrwać od Herriota, (...) w niezupełnie przekonującym tonie, (...) oświadczenie (...) że nie zamierza on ustanawiać iunctim" między własnym paktem z ZSRR a układem rumuńsko-sowieckim. Jednakże 6 sierpnia gabinet fran-

42 Telegram Herriota do przedstawicielstw w Warszawie i Bukareszcie z 3 VIII 1932 r. (nr 387-391; nr 524-528). DDF, t. I, s. 142-143; telegramy Bressy do MSZ z 6 i 10 VIII 1932, ibidem, s. 149-151, 159-160; Â. Kopanskij, I. Ė. Levit, op. cit., s. 101. 
cuski jednogłośnie zdecydował o przyjęciu iunctim, a premier został zobowiązany do udzielenia pomocy w osiągnięciu sowiecko-rumuńskiego porozumienia ${ }^{43}$.

10 sierpnia doszło do spotkania Dowgalewskiego z Légerem, w trakcie którego ten ostatni zaproponował kompromis zakładający wyeliminowanie z paktu rumuńsko-sowieckiego jakiejkolwiek wzmianki o „sporze i o terytorium znajdującym się pod suwerennością albo pod władzą"; załączenie doń protokołu końcowego zawierającego stwierdzenie, iż pakt nie może służyć do innych celów, a szczególnie do rozwiązywania kwestii spornych, istniejących między obu państwami w momencie jego podpisania; ponadto Rosjanie po zawarciu układu mogliby złożyć deklarację w „dowolnie ostrej formie” w sprawie Besarabii. Następnego dnia Sekretarz Generalny Quai d'Orsay zaproponował jeszcze sowieckiemu ambasadorowi spotkanie z Titulescu, jeśli ten przyjechałby do Paryża. 19 sierpnia Biuro Polityczne KC WKP (b) podjęło decyzję o przyjęciu francuskich propozycji dotyczących treści paktu rumuńsko-sowieckiego oraz podjęcia przez Dowgalewskiego rozmów z Titulescu ${ }^{44}$. 30 sierpnia nastąpiło uzgodnienie przez Légera i Jurija Łaszkiewicza, radcę prawnego ambasady sowieckiej w Paryżu, tekstu protokołu końcowego, w którym znalazło się sformułowanie o „spornej kwestii terytorialnej, albo innej istniejących między stronami”" ${ }^{35} .1$ września Puaux otrzymał polecenie poinformowania Palatul Sturdza, gdzie nie zdawano sobie sprawy z prowadzonych rozmów sowiecko-francuskich, o treści protokołu oraz pozostałych ustaleniach (usunięcie wzmianki o sporach terytorialnych, deklaracja dotycząca kwestii Besarabii). Poseł francuski, by „odwieść gabinet w Bukareszcie od (...) polityki odraczania" miał zasugerować, że Francja, podobnie jak wcześniej Polska, mogłaby „z powodu znaczenia i skali interesów”

43 Telegramy Dowgalewskiego z 26 VII, 2 VIII (stąd drugi cytat), 6 VIII 1932 r. do LKSZ, DVP, t. XV, s. 441-442, 449, 451-452 pismo Dowgalewskiego do Herriota z 27 VII 1932, ibidem, s. 441-442; pismo Herriota do Dowgalewskiego z 29 VII 1932 r. DDF, t. I, s. 137; raport Chłapowskiego dla A. Zaleskiego z 13 VIII 1932 r. Dokumenty i materiały do historii stosunków polsko-radzieckich. Maj 1926-grudzień 1932, t. V, Warszawa 1966, s. 596-597 (stąd pierwszy cytat); T. Sandu, op. cit., s. 403; M. Wołos, op. cit., s. 594; A. Sheviakov, op. cit., s. 38-39.

44 Telegram Dowgalewskiego do LKSZ z 10 VIII,1932 r. DVP, t. XV, s. 462-463; decyzja Biura Politycznego KC WKP (b) o Francji i Rumunii z 19 VIII 1932, O. Ken, A. Rupasov, op. cit., s. 339-341 (to samo Politbiuro TsK RKP(b)-VKP(b) i Evropa. Resheniia „osoboi papki”, 1923-1939, red. G. Adibekov i in., Moskva 2001, s. 285); pismo Dowgalewskiego do Litwinowa z 20 sierpnia 1932, DVP, t. XV, s. 481; telegram Litwinowa do Dowgalewskiego z 20 VIII 1932, SRO, s. 387-388; zob. też telegram Dowgalewskiego do LKSZ z 24 VIII 1932 r. DVP, t. XV, s. 481-485.

45 Pełny Tekst protokołu brzmiał: „Obecny pakt, zawierający zobowiązanie każdej ze stron powstrzymywania się od jakiejkolwiek agresji przeciwko drugiej, będzie interpretowany w tym sensie, że żadna sporna kwestia terytorialna albo inna, istniejąca między stronami, nie może nigdy ograniczać wspomnianego zobowiązania i nie może służyć jednej lub drugiej z umawiających się stron jako motyw lub pozostawiać im swobodę działania dla dokonania wszelkich aktów, przeczących zobowiązaniu nieagresji, ustalonemu niniejszym paktem. Rozumie się także, że pakt ten nie może służyć do innych celów, w szczególności nie może być interpretowany jako rozwiązanie wspomnianych spornych spraw, istniejących między stronami w chwili podpisania niniejszego paktu, które [to] sprawy nie są poruszone przez jego zawarcie". Telegram Dowgalewskiego do LKSZ z 30 VIII 1932, DVP, t. XV, s. 499; telegram Herriota do Puaux z 1 IX 1932, nr 567-574, DDF, t. I, s. 245-247; M. Wołos, op. cit., s. 596. 
przyśpieszyć podpisanie paktu z ZSRR, zastrzegając sobie także tak długo, jak to możliwe odraczanie ratyfikacji. Rumuni 2 września odpowiedzieli negatywnie na francuskie propozycje. W nocie przekazanej przez Crezianu francuskiemu chargé d’affaires w Bukareszcie Jeanowi Hautecloque wyrażano zdumienie, iż Francja, która była sygnatariuszem protokołu paryskiego, podważa jego postanowienia, uznając, iż Besarabia jest terenem spornym. Poinformowano Quai d'Orsay o wznowieniu przez polskie MSZ rozmów z dyplomacją ZSRR w kwestii rumuńsko-sowieckiego paktu o nieagresji, wyrażając wiarę, iż Francja będzie w tym względzie wspierać polskie wysiłki. Francuzi z pewnym żalem przyjęli odrzucenie przez Rumunów wypracowanej przez siebie formuły kompromisu z Sowietami i obiecali poprzeć starania Wierzbowej w tym kierunku ${ }^{46}$.

Wznowienie polskiej mediacji wiązało się z ustaleniami, jakie zapadły $\mathrm{w}$ trakcie wizyty wiceministra Becka w Rumunii, która odbyła się między 29 sierpnia a 1 września 1932 roku. W tym czasie oburzenie, które objawiło się nad Damboviţą na tle finalizacji polsko-sowieckiego paktu o nieagresji, uległo znacznemu osłabieniu. Bez wątpienia wpłynęło na to oświadczenie premiera Alexandru Vaida-Voevoda wygłoszone 16 sierpnia w Izbie Deputowanych, będące odpowiedzią na interpelacje posłów Iona Inculeţa i Gheorghe Brătianu dotyczące stanowiska Rumunii wobec popisania przez Polskę paktu z ZSRR. Szef rządu rumuńskiego stwierdził, iż zawarcie przez RP paktu nie osłabiło aliansu polsko-rumuńskiego i że Królestwo jest gotowe podpisać podobny pakt z Sowietami, pod warunkiem poszanowania jego prawowitych interesów. Beck w rozmowach z Gafencu, toczonych w obecności Cădere i Szembeka, stwierdził, iż podpisanie paktu z ZSRR nie oznacza zmiany osi polskiej polityki na Wschodzie i że jej fundament stanowi nadal alians z Rumunią. Wiceminister przekonywał, iż problemy wewnętrzne Związku Sowieckiego, jego skomplikowane położenie na Dalekim Wschodzie oraz osłabienie kooperacji z Niemcami, czynią go skłonnym do podpisania paktów o nieagresji z zachodnimi sąsiadami i że Rumunia powinna koniecznie skorzystać z tej możliwości. Beck nie przeceniał wartości układów z ZSRR; uważał jednak, iż mogą one przyczynić się do ustabilizowania sytuacji międzynarodowej w Europie Środkowo-Wschodniej, tworząc ,jedną całość, w ramach której pakt polsko-sowiecki byłby „pomostem między akcją Bałtów a rumuńską". Stąd też wiceszef polskiej dyplomacji zadeklarował gotowość rządu RP do udzielenia wszelkiej technicznej pomocy w nawiązaniu negocjacji i ułatwieniu porozumienia rumuńsko-sowieckiego. Jednocześnie zdecydowanie odmówił uzależnienia ratyfikacji paktu z ZSRR od finalizacji układu między Moskwą a Bukaresztem. Gafencu w imieniu rządu rumuńskiego wyraził pragnienie doprowadzenia do skutku paktu z Moskwą. Powątpiewał wprawdzie, by

46 Telegram Herriota do Puaux z 1 IX 1932 r., nr 567-574, DDF, t. I, s. 245-247 (stąd cytaty); telegramy chargé d’affaires ZSRR we Francji M. Rosenberga do Litwinowa z 2 IX, 6 IX 1932, DVP, t. XV, s. 502-503, 513-515; nota Cretzianu do francuskiego chargé d’affaires w Bukareszcie z 2 IX 1932, Behind..., s. 157-159; telegram bez podpisu do francuskiego poselstwa w Bukareszcie z 5 IX 1932, ibidem, s. 159; A.-M. Mironov, op. cit., s. 118; H. Bułhak, op. cit., s. 330; T. Sandu, op. cit., s. 405; M. Wołos, op. cit., s. 596-597; M. I. Mel'tûhov, op. cit., s. 160; Â. Kopanskij, I. Ė. Levit, op. cit., s. 101-102. 
jego podpisanie zwiększyło w sposób szczególny bezpieczeństwo Królestwa; ze sceptycyzmem odnosił się również do układów Polski i Francji z Moskwą, uważał jednak, że Rumunia powinna współpracować w tym zakresie ze swoimi sojuszniczkami, dając w ten sposób dowód solidarności z nimi w polityce wobec ZSRR. W zakresie formuły paktu Gafencu za najbardziej satysfakcjonujący uznał projekt Titulescu przekazany Schaetzlowi 22 lipca w Genewie. Należy przypuszczać, iż na taką postawę wpływała też chęć zneutralizowania głównego oponenta układu z ZSRR, jakim był poseł rumuński w Genewie. Gafencu akcentował, iż projekt Titulescu był rozwinięciem zawartego przecież przez Sowiety paktu Brianda-Kellogga. Jego część miał stanowić protokół podpisania stwierdzający, iż pakt o nieagresji nie może w żadnym razie być interpretowany w taki sposób, aby kiedykolwiek jego konsekwencją było ograniczenie lub wygaśnięcie zobowiązań wynikających z układu paryskiego. Pakt w takiej postaci rząd rumuński - zdaniem Gafencu - gotów byłby podpisać w ciągu 24 godzin (np. w Warszawie, Genewie, Wiedniu, a najlepiej w Konstantynopolu, natomiast nie w Moskwie). Jeśli jednak dyplomacja sowiecka wystąpiłaby z obiekcjami wobec propozycji Titulescu i zażądała ich modyfikacji albo też wysunęłaby życzenie powrotu do lipcowych uzgodnień Litwinow-Schaetzel, rząd rumuński byłby gotów przystać na podjęcie przez Polaków „na własną odpowiedzialność” przygotowań do rozmów, które jak wiadomo miały zostać wznowione na początku trzeciej dekady września w Genewie. Rumuński polityk przestrzegał jednak, żeby polskie zabiegi wobec ZSRR nie przekreśliły możliwości wznowienia rumuńsko-sowieckich negocjacji w Genewie oraz nie zaszkodziły stanowisku negocjacyjnemu Rumunii ani też nie ograniczyły jej swobody działania i decyzji, gdy rozmowy nad Lemanem zostaną wznowione. Prócz tego w Bukareszcie, powodując się opinią Titulescu, wyrażano zastrzeżenia wobec wynegocjowanych przez Schaetzela w rozmowach z Litwinowem sformułowań pochodzących z preambuły („obecny traktat nie może przynieść żadnej szkody w stosunkach między dwoma umawiającymi się stronami”) i artykułu I (o sprzeczności z zasadą nieagresji „,wszelkich prób, rozstrzygnięcia przemocą wszelkich sporów między dwoma umawiającymi się stronami”). Ostatecznie uzgodniono, iż dyplomacja RP wystąpi wobec Rosjan z firmowaną, jako własny projekt, propozycją Titulescu, gdy zaś zostanie ona zaakceptowana przez Moskwę, rząd rumuński natychmiast sfinalizuje pakt ${ }^{47}$.

Zadanie doprowadzenia do rozmów rumuńsko-sowieckich otrzymał ponownie Patek. Przed powrotem z urlopu do Moskwy uczestniczył on w spotkaniu w mieszkaniu Zaleskiego w Warszawie z udziałem gospodarza, Becka i Cădere. Wówczas to została „pod dyktando” posła rumuńskiego wypracowana formuła protokołu końco-

47 Telegramy Szembeka do MSZ z 16 VIII (nr 90), 17 VIII (nr 91) 1932, HIA. Rumunia. Ks. szyf., nr 6, p. 2, f. 3; deklaracja premiera Vaida-Voevodaa z 16 VIII 1932, Behind..., s. 149-150; memoranda Gafencu z 29 VIII i (?) IX (stąd pozostałe cytaty) 1932, ibidem, s. 150-156; notatka Szembeka z 1 IX 1932 z rozmów Becka w Rumunii. PDD 1932, s. 516-518 (stąd pierwsze dwa cytaty); telegram Rosenberga do Litwinowa z 6 IX1932, DVP, t. XV, 513-515; zob. też A. Călinescu, Însemări politice 1916-1939, ediţie A. G. Savu, Bucureşti 1990, s. 107; M. Manoilescu, Memorii, Vol. II, ediţie îngrijită, prefaţă, note şi indice de V. Dinu, București, 1993, s. 334; M. Gmurczyk-Wrońska, op. cit., s. 47. 
wego, którą Patek miał przedstawić Litwinowowi. Do spotkania posła RP i ludowego komisarza spraw zagranicznych doszło 13 września 1932 roku. Patek przedstawił wówczas oprócz propozycji protokołu końcowego ${ }^{48}$ projekt samego paktu. Protokół końcowy firmowany przez posła RP w Moskwie stanowił połączenie treści protokołu końcowego z wersji paktu z 22 lipca oraz kolejnego wariantu „deklaracji Patka”. Nowe sformułowanie protokołu spotkało się z zainteresowaniem szefa NKID. W jego opinii stanowiło ono krok naprzód w kierunku porozumienia sowiecko-rumuńskiego, gdyż tą drogą mógłby zostać wyeliminowany zasadniczy punkt rozbieżności między Moskwą a Bukaresztem. Natomiast drugi dokument został oceniony przez ludowego komisarza jako dwa kroki wstecz. Litwinow, który propozycje Patka znał w streszczeniu już od kilku dni, z enuncjacji Légera uczynionej nieroztropnie wobec sowieckiego chargé d'affaires we Francji Marcela Rosenberga (rozmowa z 6 września 1932 r.), upewnił się, iż są one tym samym projektem, który otrzymał od Schaetzela 22 lipca w Genewie i który odrzucił. Podjęcie obecnie dyskusji nad tym projektem równało się dla Litwinowa rozpoczęciu kolejnych negocjacji na nowych podstawach, w sytuacji, gdy według komisarza po dziewięciomiesięcznych negocjacjach pozostał do uzgodnienia tylko jeden punkt sporny. Potwierdzało to zdaniem Litwinowa wątpliwości Kremla odnośnie do szczerości i powagi zamiarów Rumunii. Patek tłumaczył, iż nie zdawał sobie sprawy, że przedłożony przez niego projekt traktatu został już wcześniej przez Rosjan odrzucony. Wskazując na złożoność położenia w kwestii paktu rumuńsko-sowieckiego, zaproponował szefowi NKID spotkanie z posłem Cădere w Warszawie lub w Wiedniu w czasie jego przejazdu do Genewy. W odpowiedzi udzielonej następnego dnia Litwinow zaproponował Berlin, sugerując od Warszawy wspólną podróż z Cădere do stolicy Niemiec i podkreślając, iż poseł rumuński winien posiadać pełnomocnictwa swego rządu na powrót do dawnej podstawy negocjacyjnej ${ }^{49}$, inaczej bowiem z rozmów mogłoby nic nie wyjść. Ludowy komisarz był skłonny przedłużyć swój jednodniowy pobyt w Berlinie o kolejną dobę, jeśli zarysowałaby się możliwość porozumienia. Gotów był także do kontynuowania rokowań w Genewie przy okazji obrad Biura Konferencji Rozbrojeniowej.

Działania Patka w Moskwie wspierał tamtejszy ambasador francuski François Dejean, informując jednocześnie Herriota o „żywym pragnieniu” Litwinowa zawarcia paktu z Rumunią. Demonstrując to dążenie, szef Narkomindiełu przekazał 15 września Patkowi, iż gotów jest spotkać się z Cădere już w Białymstoku lub Małkini i w trakcie podróży przez Warszawę do Berlina prowadzić z nim rokowania. Litwinow dalej też podtrzymywał chęć rozmów w Genewie, dodając, iż nie będzie się sprzeci-

48 „Wysokie umawiające się strony są zgodne w tym, że obecny pakt nie może być w żadnym wypadku interpretowany w ten sposób, żeby on miał w swoim następstwie ograniczenie albo wygaśnięcie zobowiązań, wynikających z paktu podpisanego w Paryżu 27 sierpnia 1928 r. On [obecny pakt] nie ma innego celu, oprócz nieagresji i nie może być interpretowany dla innych celów, ani przynieść uszczerbku pozycji żadnej ze stron w sporach między nimi”. Zapis rozmowy Litwinowa z Patkiem z 13 IX 1932 DVP, t. XV, s. 526-527; telegram Dejeana do Herriota z 14 IX 1932 r. (nr 162-165), DDF, t. I, s. 318-319.

49 Litwinow za taką uważał projekt paktu wręczony Zaleskiemu 5 lipca 1932 r. Załącznik do telegramu Litwinowa do LKSZ z 5 VII 1932, SRO, s. 373-376. 
wiał ewentualnemu życzeniu Rumunów prowadzenia ich w Chamonix, Aix les Bains, Lyonie albo innym nieodległym miejscu, gdzie mógłby dojechać z Genewy w trakcie przerwy między posiedzeniami Biura Konferencji Rozbrojeniowej. Sugestię Patka dyskutowania innych projektów niż projekt uważany za starą podstawę Litwinow odrzucił, stwierdzając, iż będzie to potraktowane przez Rosjan jako zerwanie negocjacji przez Rumunię, a Polska i Francja otrzymają stosowne oświadczenia ${ }^{50}$.

W świetle instrukcji otrzymanej od Gafencu, Cădere miał rozmawiać z Litwinowem jedynie na terytorium Polski. Odżegnanie się od wyjazdu do Berlina i prowadzenia tam negocjacji miał uzasadnić trudnościami technicznymi, brakiem czasu oraz obawą przed ujawnieniem ich tajemnicy. Poseł rumuński otrzymał pełnomocnictwa jedynie do nawiązania wstępnych rozmów $z$ Litwinowem, lecz nie do prowadzenia pertraktacji. W rozmowach z szefem NKID miał demonstrować gotowość rządu rumuńskiego do zawarcia paktu z ZSRR, jednakże według projektu z 22 lipca i bez wprowadzania doń modyfikacji. Jego zadaniem było zdystansowanie się w imieniu Bukaresztu od nowej formuły protokołu końcowego przedstawionej przez Patka 13 września w Moskwie. Pikanterii temu zadaniu dodaje fakt, iż Cădere był jej głównym autorem.

Gafencu zdawał sobie sprawę, iż rozmowy Cădere z Litwinowem nie przyniosą żadnego efektu. W obawie przed zarzutami ze strony Polaków nakazał posłowi manifestować przed Beckiem, iż nie uchyla się od kontaktu z Litwinowem i że nie ponosi odpowiedzialności za rezultat rozmów ${ }^{51}$.

17 września Cǎdere wsiadł w Białymstoku do wagonu Litwinowa i w drodze do Warszawy przeprowadził z nim dwugodzinną rozmowę. Zgodnie z instrukcjami z Bukaresztu poseł rumuński zadeklarował w imieniu swego rządu gotowość zawarcia paktu w wersji z 22 lipca. Szef NKID po dyskusji, w której forsował własny projekt, wysunął pomysł rozpatrzenia wspólnych elementów obu projektów i stworzenia z nich jednego kompromisowego. Litwinow zaproponował przyjęcie preambuły z projektu rumuńskiego i wyrzeczenie się 4 akapitu preambuły własnego projektu, w którym była mowa o „terytorialnym sporze i innych istniejących między [stronami - HW] (...), i że spory te pozostają na boku i w żadnym stopniu nie będą poruszone w (...) pakcie”. Odnośnie do artykułu I projektu sowieckiego zapowiedział rezygnację z części akapitu 2, gdzie znajdowała się również wzmianka o „terytorialnym albo innych sporach". W zamian oczekiwał od Rumunów odejścia od redakcji art. 1 ich projektu, która nie dotyczyła bezpośrednio funkcjonowania paktu o nieagresji, a nawiązywała

50 Telegramy Rosenberga do Litwinowa z 6 IX, 13 IX 1932 r. DVP, t. XV, s. 513-515, 527-528; zapis rozmowy Litwinowa z Patkiem z 16 X 1932, ibidem, s. 576-577 (stąd cytat); telegram Litwinowa do Rozenberga z 9 IX 1932, ibidem, s. 513-515; zapis rozmowy Litwinowa z Patkiem z 13 IX, 14 IX (wraz z załącznikiem), 1932, ibidem, s. 522-527, 530-531; zapis rozmowy Litwinowa z Patkiem z 15 IX 1932, SRO, s. 391-392; telegram Dejeana do Herriota z 14 IX 1932 r. (nr 162-165), DDF, t. I, s. 318-319; telegram Cǎdere do Gafencu z 15 IX 1932, Behind..., s. 161-163; telegram Becka do poselstwa w Bukareszcie z 17 IX 1932, nr 109, HIA. Rumunia. Ks. szyf., nr 6, p. 2, f. 3; zob. memorandum Cretzianu z 9 IX 1932 r., Behind..., s. 160-161; M. I. Mel'tûhov, op. cit., s. 161; zob. J. Beck, op. cit., s. 33.

51 Odpowiedź Gafencu na telegram Cǎdere z 15 IX 1932 r., Behind..., s. 161-163; telegram Gafencu do Cădere z 15 IX 1932, SRO, s. 391-392; telegram Szembeka do MSZ z 15 IX 1932, nr 100, HIA. Rumunia. Ks. szyf., nr 6, p. 2, f. 3. 
do paktu Brianda-Kellogga, odgrywającego jego zdaniem w tym kontekście drugorzędną rolę. Lepszym rozwiązaniem według Litwinowa byłoby umieszczenie w tym miejscu kategorycznego stwierdzenia, że obie strony „ostatecznie wyrzekają się agresji dla usunięcia jakichkolwiek sprzeczności między nimi”. Do przyjęcia był zdaniem ludowego komisarza artykuł 2 projektu rumuńskiego, pod warunkiem zredagowania go w sposób bliższy artykułowi 1 ustęp 2 projektu sowieckiego. Użyteczny według Litwinowa byłby artykuł 3 projektu rumuńskiego, pod warunkiem wprowadzenia doń z projektu sowieckiego (art. 2) kategorycznego sformułowania o możliwości „wypowiedzenia (...) paktu bez uprzedzenia przez jedną ze stron jeśli druga dopuściłaby się napaści na państwo trzecie"; sformułowanie to zastąpiłoby niewyraźne zdaniem komisarza stwierdzenie z paktu rumuńskiego o pozbawieniu przez jedną ze stron „korzyści niniejszego paktu”, jeśli druga dopuściłaby się agresji wobec państwa trzeciego. Konieczne w opinii szefa NKID było utrzymanie w pakcie art. 4 z projektu sowieckiego mówiącego, iż żadne międzynarodowe zobowiązania, wcześniej przyjęte przez jedną ze stron, nie stanowią przeszkody dla istnienia pokojowych stosunków $\mathrm{z}$ drugą stroną i nie przeczą paktowi i że obie strony zobowiązują się na przyszłość do niewchodzenia w jakiekolwiek porozumienia, które znalazłyby się formalnie albo faktycznie w sprzeczności z paktem. Zgoda Rumunii na ten artykuł byłaby w opinii Litwinowa dowodem na jej „szczere zamiary”, zwłaszcza jeśli chodzi o nieagresję. W protokole podpisania ludowy komisarz proponował przyjęcie formuły możliwie szerokiej, zawierającej stwierdzenie o „sporach między dwoma stronami” i wzmiankę o pośrednictwie Francji w zawarciu paktu. Jak widać z rozmów z Cădere, szef dyplomacji sowieckiej nie odbiegał w swoich propozycjach ${ }^{52}$ wobec Rumunów od formuły paktu przesłanej do Bukaresztu z Quai d’Orsay kilkanaście dni wcześniej, traktowanej tam jako podstawa do wypracowania kompromisu sowiecko-rumuńskiego. Litwinow liczył zapewne, iż Paryż będzie naciskał na przyjęcie tych propozycji przez Palatul Sturdza, a będąca skutkiem tych nacisków finalizacja paktu z Rumunami przyśpieszy zawarcie układu sowiecko-francuskiego. Poseł rumuński nie miał, jak wiadomo, pełnomocnictw do negocjacji z Litwinowem ani ku ubolewaniu tego ostatniego zgody na wyjazd do Berlina. Szef NKID nie robił złudzeń swojemu interlokutorowi, iż przyjmie bez zastrzeżeń projekt rumuński z 22 lipca. To samo stanowisko przedstawił w Warszawie Zaleskiemu i Beckowi, wywołując w nich przekonanie, iż zawarcie paktu rumuńsko-sowieckiego poprzez uzupełnienia albo modyfikację projektu z 5 lipca jest zupełnie możliwe. Dlatego też w Warszawie pozytywnie odniesiono się do sugestii Litwinowa kontynuowania negocjacji w Genewie, albo w jej pobliżu, i oferując bons offices, namawiano Cǎdere do wyjazdu nad Jezioro Lemańskie. Jednocześnie Polacy, Rosjanie i Francuzi, a także rumuńskie MSZ obawiali się storpedowania tam rokowań przez Titulescu ${ }^{53}$.

52 Usunięcie z paktu wzmianek o sporze terytorialnym i innych istniejących oraz przesunięcie tej kwestii do protokołu końcowego - przyp. HW.

53 Raport Cǎdere do premiera Vaida-Voevoda z 17 IX 1932, SRO (stąd cytaty), s. 392-395; telegram Litwinowa do LKSZ z 17 IX 1932, ibidem, s. 396; telegram Szembeka do MSZ z 17 IX 1932, nr 101, HIA. Rumunia. Ks. szyf., nr 6, p. 2, f. 3; telegram Becka do poselstwa w Bukareszcie z 17 IX 
20 września odbyła się w pałacu w Sinaia narada z udziałem Karola II, premiera Vaida-Voevoda, Gafencu i Cădere. Ustalono, iż dla kontynuacji rokowań z Litwinowem uda się do Genewy poseł rumuński w Warszawie, a w razie potrzeby wyjedzie tam również Gafencu. W rozmowie z posłem francuskim Puaux, Vaida-Voevod i Gafencu zdystansowali się od prowadzenia rozmów na płaszczyźnie formuły Patka (pakt „nie może (...) przynieść uszczerbku pozycji żadnej ze stron w sporach między nimi”) przedstawionej Litwinowowi 13 września 1932 roku. Nie chcieli także, mimo nacisku Puaux, przystać na formułę francuską („,̇adna sporna kwestia terytorialna albo inna, istniejąca między stronami, nie może nigdy ograniczać wspomnianego zobowiązania [tj. nieagresji]"), uważając, że żaden rumuński rząd nie może podpisać z ZSRR paktu, choćby aluzyjnie wspominającego Besarabię ${ }^{54}$.

Przed wyjazdem Cǎdere otrzymał od szefa rządu instrukcję. Został w niej upoważniony do podjęcia rozmów z Litwinowem i zaparafowania paktu o nieagresji. Według premiera najbardziej pożądane byłoby przeforsowanie projektu autorstwa Titulescu znanego już Rosjanom z rozmów z Schaetzelem (22 lipca) i Patkiem (13 września). Jeśli okazałoby się to niemożliwe, podstawą negocjacji miały stać się ustalenia poczynione w Rydze przez Stomoniakowa i Sturdzę, uwzględnione w projekcie paktu przekazanym Zaleskiemu przez Litwinowa 5 lipca 1932 roku. Vaida-Voevod brał pod uwagę likwidację artykułu IV wspomnianego projektu i w związku z tym życzył sobie uzupełnienia preambuły o akapit stwierdzający, iż obie strony, „zdając sobie sprawę, że żadne z tych zobowiązań (chodzi o międzynarodowe zobowiązania wcześniej podjęte przez Rumunię i ZSRR - przyp. HW) nie może stanowić przeszkody dla pokojowego rozwoju ich wzajemnych relacji i nie znajduje się w sprzeczności z obecnym Traktatem, w równym stopniu nie zdecydują się zawierać w przyszłości niczego sprzecznego z obecnym Traktatem". Z kolei artykuł I projektu z 5 lipca pozbawiony passusu stwierdzającego sprzeczność ze zobowiązaniem nieagresji „każdej próby rozwiązania siłą sporów terytorialnego albo innego”, miał zawierać stwierdzenie o sprzeczności z tym zobowiązaniem „każdego aktu gwałtu, skierowanego przeciwko całości i nietykalności terytorium lub też politycznej niezależności drugiej Umawiającej się Strony":

- „nawet jeśli takie akty zostałyby popełnione bez wypowiedzenia wojny i z uniknięciem wszystkich jej możliwych konsekwencji” (pierwszy wariant);

- „jak również każdej próby, rozwiązania gwałtem jakiegokolwiek sporu między dwoma Umawiającymi się Stronami nawet jeśli takie akty zostałyby popełnione bez wypowiedzenia wojny i z uniknięciem wszystkich jej możliwych konsekwencji" (drugi wariant).

Do artykułu III zakazującego pobytu lub działalności na terytorium każdego z państw, organizacji zbrojnie występujących przeciwko kontrahentowi oraz osób

1932, nr 109, ibidem; A. Călinescu, op. cit., s. 107; M. I. Mel'tûhov, op. cit., s. 161; A.-M. Mironov, op. cit., s. 118-119; Â. Kopanskij, I. Ė. Levit, op. cit., s. 102-103.

54 A. Vaida-Voevod, Memorii, Vol. II, s. 235; telegram Puaux do Herriota z 20 IX 1932, La Grande Roumanie alliée..., s. 235-236 (stad cytaty); telegram Szembeka do Schaetzela z 21 IX 1932, HIA. Rumunia. Ks. szyf., nr 6, p. 2, f. 3. 
uzurpujących sobie rolę rządu lub reprezentacji terytorium drugiego z państw, dodano passus zabraniający organizacjom już istniejącym na terenie każdego z państw „angażowania się jakimkolwiek sposobem w prowokowanie lub rozbudzanie politycznych zamieszek lub społecznych problemów na obszarze drugiego". Treść artykułu IV miała być zbliżona do analogicznego artykułu projektu z 5 lipca, jeśli nie doszłoby do wprowadzenia cytowanego już zapisu w preambule. Artykuły II, V i VI w minimalnym stopniu różniły się od swoich odpowiedników z projektu sowieckiego. Odnośnie do protokołu podpisania, premier Vaida-Voevod proponował dwa warianty. Pierwszy zawierał stwierdzenie, iż traktat nie może być interpretowany jako skutkujący ograniczeniem lub wygaśnięciem zobowiązań wynikających z układu paryskiego z 1928 r.; konstatowano, iż żadna sporna kwestia nie może ograniczyć zobowiązania nieagresji zawartego $\mathrm{w}$ traktacie ani stanowić motywu sprzeniewierzenia się temu zobowiązaniu przez któregoś z sygnatariuszy; stwierdzano również, iż traktat nie może być interpretowany do innego celu niż nieagresja. Wariant drugi protokołu podpisania różnił się od pierwszego brakiem konstatacji o nieograniczaniu zobowiązania nieagresji przez jakąkolwiek kwestię sporną ${ }^{55}$.

23 września Gafencu w imieniu rządu rumuńskiego zwrócił się do warszawskiego MSZ z propozycją zawarcia tajnego lub jawnego polsko-francusko-rumuńskiego protokołu, w którym sygnatariusze zobowiązywaliby się do wzajemnego porozumienia w sprawie przedłużenia lub odnowienia swoich paktów o nieagresji ze Związkiem Sowieckim przed terminem ich wygaśnięcia. Podsekretarz stanu wskazywał, iż Moskwa mogłaby po upływie trzech lat wypowiedzieć jednemu z państw podpisany z nim pakt, co musiałoby doprowadzić do osamotnienia tego państwa i pogorszenia jego położenia międzynarodowego. Proponowany protokół mógłby zapobiec takiej sytuacji, cementując solidarność polsko-francusko-rumuńską i tym samym wzmocnić wartość poszczególnych układów o nieagresji. Podpisanie protokołu byłoby atutem dla rządu rumuńskiego przy forsowaniu zawarcia paktu z ZSRR, szczególnie wobec wrogiej temu przedsięwzięciu akcji Titulescu ${ }^{56}$.

Brak szybkiej odpowiedzi spowodował nalegania Vaida-Voevoda i Gafencu na przyjęcie przez Polskę ich propozycji. Sugerowano, iż mogłaby zostać ona zrealizowana $\mathrm{w}$ formie échange de lettres. Rumunom zależało tym bardziej na partnerstwie Warszawy, gdyż Francuzi sceptycznie odnieśli się do koncepcji trójstronnego protokołu, stwierdzając, iż jest on niepotrzebny, albowiem jego zobowiązania dublują się z sojuszem rumuńsko-francuskim. Rumuni zabiegali również bezskutecznie o podjęcie przez Paryż akcji zmierzającej do wymuszenia na Sowietach deklaracji, w której zobowiązywaliby się od niestosowania przemocy wobec Królestwa i respektowali jego status terytorialny. Brak pozytywnej reakcji francuskiej spowodował rozdrażnienie w Bukareszcie oraz upowszechnianie opinii, iż Francja lekceważy interesy

55 Instrukcja Vaida-Voevodaa do Cǎdere z 21 IX 1932, Behind..., s. 167-171; Telegram Kobylańskiego do Zaleskiego z 23 IX 1932, HIA. Rumunia. Ks. szyf., nr 6, p. 2, f. 3.

56 Telegramy Kobylańskiego do MSZ z 23 IX (102), 28 IX (nr 105) 1932, ibidem; zob. Â. Kopanskij, I. È. Levit, op. cit., s. 103. 
rumuńskie wobec ZSRR. Bukareszteńskie MSZ zintensyfikowało zatem starania o uzyskanie poparcia ze strony Polski. W tym czasie Titulescu przebywający na kuracji w Austrii został zawiadomiony przez jadącego do Genewy Cădere o ustaleniach podjętych w Sinaia w sprawie rokowań z ZSRR. Jego reakcją było podjęcie na łamach prasy otwartych ataków na własny rząd, a następnie dymisja $\mathrm{z}$ funkcji przewodniczącego delegacji rumuńskiej w Lidze Narodów i wyjazd do Londynu, gdzie pełnił funkcję posła ${ }^{57}$.

Działania Titulescu, a zwłaszcza enuncjacja stwierdzająca, iż pakt Brianda-Kellogga jest „wystarczającym układem i Rumunia nie jest zainteresowana w zawieraniu innych paktów", wywołały zaniepokojenie na Wierzbowej. W opinii Becka oświadczenia Titulescu pozostawały w sprzeczności z deklaracjami rządu rumuńskiego na temat kontynuowania pertraktacji z Moskwą. Wiceminister nazwał to wręcz „dywersją”. W tej sytuacji Polsce trudno byłoby rozważać kwestię zawarcia protokołu, gdy pod znakiem zapytania stanęła sprawa sfinalizowania paktu sowiecko-rumuńskiego. Beck deklarował, iż Polacy gotowi są do „najszczerszej współpracy”, jednakże „Wobec takiej sprzeczności opinii rumuńskich kół politycznych (...) rządowi polskiemu trudno jest wiązać swą politykę w sprawie paktu o nieagresji jakimś nowym trwałym układem". Stanowisko Becka zostało nieco złagodzone, gdy okazało się, że Cădere podjął jednak w Genewie rokowania z Litwinowem. Wiceminister nadal co prawda nie był przekonany do propozycji podpisania z Rumunią specjalnego protokołu dotyczącego przedłużania paktów z ZSRR, to jednak uważał, iż po zawarciu rumuńsko-sowieckiego układu o nieagresji „porozumienie i ścisła współpraca polsko-rumuńska w dziedzinie wykonywania i odnawiania” tego układu „będzie rzeczą oczywistą" 58 .

Negocjacje Cădere - Litwinow toczyły się pomiędzy 28 września a 5 października. Już pierwszego dnia uzgodniono w zasadzie treść paktu. Była ona niemal identyczna z projektem zawartym w instrukcji Vaida-Voevoda do Cădere z 21 września. Różnice zdań pojawiły się odnośnie do artykułu III, który w końcu został za zgodą obu stron usunięty. Zmieniono redakcję artykułu IV, zastępując sformułowanie o niepodejmowaniu przez strony w przyszłości żadnych zobowiązań będących „formalnie albo faktycznie w sprzeczności z obecnym układem" frazą o nieprzyjmowaniu zobowiązań, „które byłyby sprzeczne z duchem obecnego układu”. Ustalono też, że wymiana dokumentów ratyfikacyjnych (art. VI) odbędzie się w Istambule.

Rozbieżności pojawiły się, gdy Litwinow zażądał, ażeby zostały dodane słowa „terytorialne spory i różnice interesów”. Wywiązała się dłuższa dyskusja, w trakcie której komisarz zaproponował jako kompromis rezygnację ze słów „terytorialne

57 Telegram Kobylańskiego do MSZ z 26 IX 1932, nr 103, HIA. Rumunia. Ks. szyf., nr 6, p. 2 , f. 3; telegram Légera do Puaux z 27 IX 1932, La Grande Roumanie alliée..., s. 237-238; sprawozdanie ppłk Michałowskiego z 29 X 1932 r. AAN. SztG. 616, t. 173, k. 789; A. Vaida-Voevod, Memorii, Vol. II, s. 238-239; M. Manoilescu, op. cit., s. 334; A. Călinescu, op. cit., s. 106; F. C. Nanu, Politica externă a României 1918-1933, traducere de L. Roşca şi E. Ungureanu, Iaşi 1993, s. 157.

58 Telegram Becka do poselstwa w Bukareszcie z 26 IX (nr 103 - stąd cytaty), 28 IX (nr 111) 1932, HIA. Rumunia. Ks. szyf., nr 6, p. 2, f. 3; zob. A. Călinescu, op. cit., s. 106. 
spory” i wprowadzenie do preambuły stwierdzenia, że „zawarcie obecnego traktatu nie przyniesie jakiegokolwiek uszczerbku pozycji żadnej z stron w sporach istniejących między nimi” (uzupełniona o słowo „istniejące” formuła Patka). Delegat rumuński nie chciał się zgodzić na tę wersję. Ustalono zatem kontynuowanie rozmów 1 października. Dyskutowano wówczas głównie nad treścią protokołu podpisania, biorąc za punkt wyjścia pierwszy wariant z instrukcji Vaida-Voevoda z 21 września, który został Rumunom narzucony przez Francuzów, a Rosjanom podany do wiadomości 29 tego miesiąca. Spotkanie zakończyło się impasem. Wprawdzie Cădere przedstawił szereg nowych formuł, to jednak nie zawierały one słowa „istniejący” i zostały odrzucone przez szefa Ludowego Komisariatu Spraw Zagranicznych ${ }^{59}$.

Rumuński delegat 2 października podjął konsultacje z Palatul Sturdza, w trakcie których wyraził przekonanie, iż Litwinow, pod wpływem nacisku Francuzów, mógłby zrezygnować ze wzmianki o „istniejących sporach” na rzecz stwierdzenia $\mathrm{o}$ „wszystkich przeszłych, obecnych lub przyszłych sporach” lub też sformułowania $\mathrm{o}$ „kwestiach jeszcze nieuregulowanych”. Bukareszt nie był jednak skłonny do szybkich ustępstw. Premier Vaida-Voevod pisał do Cǎdere, że tylko w wypadku groźby zerwania rokowań mógłby wprowadzić do protokołu podpisania wzmianki o ,sporze jakiejkolwiek natury” albo „przeszłych, obecnych lub przyszłych sporach”, względnie o „kwestiach jeszcze nie uregulowanych”. Nie mając jasnych dyspozycji, Cădere 3 października „nieoficjalnie” $i$ „we własnym imieniu” zaproponował ludowemu komisarzowi następujące sformułowanie: „Strony są zgodne, że pakt ma na celu tylko zabezpieczenie istniejącego pokoju wzajemnym zobowiązaniem nieagresji i nie będzie interpretowany dla jakichkolwiek innych celów, ani nie przesądza obecnych i przyszłych sporów między nimi”. Litwinow odmówił rozpatrywania tej propozycji bez usankcjonowana przez Bukareszt. W swojej korespondencji do Stalina stwierdził wszakże, iż zaproponowana formuła jest dla ZSRR do przyjęcia, zwłaszcza, że pakt jest już uzgodniony; prócz tego Związek Sowiecki mógłby znaleźć się w nie najlepszym położeniu, gdyby okazało się, iż negocjacje z Rumunią, podpisanie paktu z Francją i ratyfikacja układu z Polską zostały przerwane lub zawieszone z powodu trudno uchwytnej różnicy pomiędzy słowami „istniejący” i „obecny”. Następnego dnia Moskwa odniosła się pozytywnie do sprawy, a Litwinow otrzymał polecenie podpisania paktu. Jednakże wtedy właśnie Cădere wycofał się ze swojej propozycji ze względu na odrzucenie jej przez Bukareszt. Nastąpiło wówczas usztywnienie stanowiska szefa NKID, który zażądał niezwłocznego zaakceptowania protokołu z formułą „istniejących sporów”. Zaczął też podnosić uzgodnione wcześniej w toku negocjacji kwestie sporne. Nie mogąc wypracować kompromisu w sprawie proto-

59 Telegram Cǎdere do Vaida-Voevoda z 28 IX 1932, Behind..., s. 173-174 (stąd cytaty); telegram chargé d'affaires Rosenberga do LKSZ z 29 IX 1932; DVP, t. XV, s. 546; telegram Litwinowa do LKSZ z 3 X 1932 r. wraz z załącznikiem. SRO, s. 397-399; telegram Kobylańskiego do MSZ z 29 IX 1932, HIA. Rumunia. Ks. szyf., nr 6, p. 2, f. 3; A. Skrzypek, Zagadnienia rumuńskie..., s. 193; V. Bystrický, L. Deák, Európa na prelome. Diplomatické a politické vztahy v rokoch 1932-1933, Bratislava 1974, s. 172; L. Pădureac, op. cit., s. 83; A.-M. Mironov, op. cit., s. 119; A. Sheviakov, op. cit., s. 41; zob. F. C. Nanu, op. cit., s. 157; D. Hrenciuc, op. cit., s. 26. 
kołu podpisania, obaj dyplomaci ustalili, iż następnego dnia spotkają się ponownie, aby nie tworzyć wrażenia, że pertraktacje zostały rozbite.

Tego samego dnia odbyła się konferencja Cădere z Zaleskim, Schaetzelem i Massiglim, w trakcie której dyplomata rumuński przedstawił swoim partnerom efekty rozmów z Litwinowem. Aby uczynić komisarza bardziej skłonnym do ustępstw, ustalono, iż następnego dnia rano Schaetzel i Massigli złożą na jego ręce zbiorowe démarche $z$ deklaracją, iż Francja jest gotowa podpisać, a Polska ratyfikować swój pakt z ZSRR, jeśli ten podpisze z Rumunią układ o nieagresji z protokołem podpisania niezawierającym słowa „istniejący"60.

Pomimo démarche Massigliego i Schaetzela, Litwinow w rozmowie z Cădere 5 października nie zmienił swego stanowiska w kwestii treści protokołu podpisania. Obaj dyplomaci skonstatowali wszakże, iż dyskusja nadal pozostaje otwarta i negocjacje mogłyby zostać wznowione po 10 października w Genewie lub nawet wcześniej w Paryżu. Podsumowując ostatnie dwa dni negocjacji z szefem LKSZ, Cădere stwierdził jego rosnący brak elastyczności spowodowany podatnością „na prądy wrogie naszym sojusznikom". Gafencu przypisywał to wpływom Niemiec i Włoch, które w ten sposób chciały storpedować finalizację paktu francusko-sowieckiego. Odnośnie do dalszych losów negocjacji Cădere uważał, iż przerwa może być dla nich pożyteczna. Przed ich wznowieniem jednak Polska i Francja powinny spowodować zaakceptowanie przez Litwinowa ostatecznego tekstu układu ${ }^{61}$.

Z pewnym optymizmem na perspektywy rokowań rumuńsko-sowieckich spoglądał wiceminister Beck. Konstatował on fakt uzgodnienia tekstu paktu oraz pozostawanie do uregulowania ,jedynie słowa existants”. W jego przekonaniu nie była to istotna przeszkoda, by miała decydować o przyszłym charakterze stosunków rumuńsko-sowieckich. Wiceszef polskiej dyplomacji wskazywał, iż Cǎdere nie wykorzystał dotąd upoważnienia rządu rumuńskiego do zastąpienia słów „istniejące spory” przez określenie „kwestie jeszcze nieuregulowane”. W opinii Becka w zasadzie obie formuły były do przyjęcia dla rządu sowieckiego; jego dotychczasowy opór tłumaczył gospodarz Wierzbowej „przede wszystkim względami taktycznymi”62.

Rozwój wydarzeń na rumuńskiej scenie politycznej budził coraz większe zaniepokojenie polskich dyplomatów. Przyjęcie przez rząd Vaida-Voevoda dymisji Titulescu spowodowało kryzys w koalicji rządowej i groźbę wyjścia z gabinetu ministrów reprezentujących Narodową Partię Chłopską z ministrem Mihalache na czele. Aby spa-

60 Memorandum Gafencu z 2 X 1932, Behind..., s. 175-176 (stąd cytaty); telegram Kobylańskiego do MSZ z 2 X 1932, HIA. Rumunia. Ks. szyf., nr 6, p. 2, f. 3; telegram Litwinowa do Stalina z 3 X, 1932, SRO, s. 397; telegram Karachana do Litwinowa z 4 X 1932, ibidem, s. 399; wywiad Litwinowa dla przedstawiciela TASS z 16 X 1932, ibidem, s. 400-404; telegram Vaida-Voevoda do Cădere z 3 X 1932, Behind..., s. 177; telegram Cădere do Vaida-Voevoda z 4 X 1932, ibidem, s. 178; O. Ken, A. Rupasov, op. cit., s. 351-352; L. Pădureac, op. cit., s. 83; M. I. Mel'tûhov, op. cit., s. 161; E. Bold, R. O. Locovei, op. cit., s. 142; Â. Kopanskij, I. Ė. Levit, op. cit., s. 104-105.

61 Telegram Cădere do Vaida-Voevoda z 5 X 1932, Behind..., s. 179-180 (stąd cytat); telegram Kobylańskiego do MSZ z 5 X 1932, HIA. Rumunia. Ks. szyf., nr 6, p. 2, f. 3.

62 Telegram Becka do poselstwa w Bukareszcie z 7 X 1932, ibidem. 
cyfikować kryzys, premier podjął grę z Titulescu i zaproponował mu 9 października wejście w skład gabinetu, na co ten się zgodził. Dzień później Vaida-Voevod udzielił wywiadu prasowego, w którym przedstawił przebieg negocjacji dotyczących paktu o nieagresji, uwypuklając „dywersyjną rolę” Titulescu i podkreślając niedopuszczalność dwutorowości działań rumuńskiej polityki zagranicznej. Premier wskazał na uchylanie się Titulescu od odpowiedzialności i wyraził nadzieję, że objęcie przezeń fotela ministra spraw zagranicznych zmieni ten stan rzeczy. Szef rządu nadal podtrzymywał swoje pozytywne stanowisko w sprawie paktu z ZSRR i zapowiedział wznowienie rokowań. W ocenie Kobylańskiego Vaida-Voevod poprzez enuncjację chciał zmusić swego adwersarza do dobrowolnego wycofania się z rządu. Premier brał także pod uwagę możliwość dymisji rady ministrów, jeśli Titulescu nie chciałby przyjąć jej nastawienia w sprawie paktu ze Związkiem Sowieckim ${ }^{63}$.

Tymczasem Titulescu, formalnie nie sprawując jeszcze funkcji ministra, poczynił w Paryżu deklaracje, które doprowadziły do kolejnego wzrostu napięcia z premierem Vaida-Voevodem. W rozmowach na Quai d’Orsay dyplomata rumuński stwierdził, iż dyskutowany w Genewie projekt paktu z ZSRR nie tylko nie przynosił Rumunii nowych gwarancji bezpieczeństwa, ale osłabiał układ Brianda-Kellogga, zawierając limit 5 lat jako okres obowiązywania; poza tym ewentualne wprowadzenie do paktu pojęcia sporu mogło otworzyć w odniesieniu do Besarabii drogę do arbitrażu i plebiscytu. Titulescu, formalnie deklarując chęć rozmów z ZSRR, zapowiadał modyfikacje treści paktu. Jednocześnie informował, iż nie ma żadnych obiekcji przed podpisaniem przez Francję jej paktu z ZSRR i ratyfikacją polsko-sowieckiego układu o nieagresji. Wyrażał też życzenie, by Paryż, podpisując układ z Moskwą, uzyskał z jej strony dla Rumunii deklarację o nieagresji. Titulescu oprócz oficjalnych enuncjacji, które raczej maskowały jego intencje, odkrył swe prawdziwe intencje w poufnej rozmowie z Herriotem i Berthelotem. Oznajmił im, że nie zamierza doprowadzić do paktu z ZSRR i „że będzie (...) przez jakiś czas udawać negocjowanie, by wina zerwania spadła na Sowiety" 64 .

Przesilenia rządowego, na który wpływ miała działalność Titulescu, nie udało się przezwyciężyć. 17 października premier Vaida-Voevod zgłosił królowi Karolowi II dymisję gabinetu, która została przyjęta. Nowym szefem rządu został Iuliu Maniu, a gospodarzem Palatul Sturdza - Nicolae Titulescu ${ }^{65}$.

Wynurzenia Titulescu w Paryżu nie pozostawiały złudzeń polskiej dyplomacji odnośnie do jego stanowiska w kwestii paktu z Moskwą. Beck jednak polecił powia-

63 Telegramy Kobylańskiego do MSZ z 8 X (nr 113, 114), 9 X (nr 115), 11 X (nr 116 - cytat, 117) 1932, ibidem; zob. A. Dubicki, Nicolae Titulescu. Portret polityka i dyplomaty, Łomianki 2010, s. 156; Â. Kopanskij, I. Ė. Levit, op. cit., s. 105-107.

64 Telegram Becka do poselstwa w Bukareszcie z [X 1932], ibidem, Tel. osob. ks. 1; telegram Szembeka do MSZ z 14 X 1932 (nr 118), ibidem, Ks. szyf., nr 6, p. 2, f. 3; telegram Légera do Puaux z 13 X 1932, La Grande Roumanie alliée..., s. 239-241; M. Manoilescu, op. cit., s. 234-235; Â. Kopanskij,

I. È. Levit, op. cit., s. 107-108.

65 I. Scurtu, G. Buzatu, Istoria Românilor în secolul XX (1918-1948), București 1999, s. 252; D. Hrenciuc, op. cit., s. 26. 
domić premiera Maniu o treści poufnych rozmów rumuńskiego dyplomaty prowadzonych nad Sekwaną. Wskazywał, iż postawa Titulescu jest sprzeczna z deklaracjami wcześniejszych gabinetów rumuńskich o chęci podpisania z Moskwą układu o niestosowaniu przemocy oraz odprężenia we wzajemnych relacjach; według wiceszefa polskiego MSZ pozostawała także w kolizji z enuncjacjami samego Titulescu czynionymi wobec Warszawy. Beck nakazał podkreślić, iż oświadczenie Litwinowa względem Patka z 16 października o gotowości odstąpienia od słowa „existants” na rzecz „présents et futures” wskazuje na dobrą wolę ZSRR w kwestii finalizacji paktu z Rumunią. Wiceszef polskiej dyplomacji konstatował, iż w tych okolicznościach wina za zerwanie rokowań spadnie nieuchronnie na władze w Bukareszcie, natomiast rząd polski, „który zawsze był gotów do lojalnej współpracy w kwestii paktu” nie będzie mógł „dać się użyć za narzędzie gry politycznej rokowań skazanych z góry na zerwanie"66.

W ciągu kilku następnych dni Beck utwierdził się w przekonaniu, iż koncepcja dalszych wspólnych działań polsko-rumuńskich stała się nieaktualna ze względu na niechętną rokowaniom postawę rządu królewskiego. 25 października nowy gospodarz Palatul Sturdza w rozmowie z Szembekiem obłudnie złożył wyrazy podziękowania pod adresem Becka za pomoc w dotychczasowych negocjacjach z Sowietami i zadeklarował ich kontynuację pod określonymi warunkami. Wiceszef polskiej dyplomacji, zdając sobie sprawę z tej gry, polecił oświadczyć Titulescu, iż Polska staje na stanowisku désintéressement co do dalszych pertraktacji rumuńsko-sowieckich i rezerwuje sobie wolną rękę w sprawie finalizacji swojego paktu ze Związkiem Radzieckim. Informację tę Szembek przekazał Titulescu 29 października. Pytanie Rumuna, czy odpowiedź rządu polskiego licuje z tonem jego enuncjacji sprzed czterech dni, poseł RP pozostawił bez komentarza. 23 listopada Titulescu wygłosił w Izbie Deputowanych przemówienie w którym stwierdził, iż wysiłki rządu rumuńskiego odnośnie do zawarcia paktu z ZSRR nie doprowadziły do pozytywnych rezultatów i nie ponosi on $\mathrm{z}$ tego powodu żadnej winy. Wyrażając uznanie dla solidarnej i lojalnej wobec Bukaresztu postawy Warszawy i Paryża, podkreślił, iż urzeczywistnienie paktów obu państw będzie korzystne dla Rumunii. 26 listopada prezydent RP Ignacy Mościcki ratyfikował polsko-sowiecki pakt o nieagresji. Dzień później uczynił to ze strony sowieckiej Michaił Kalinin - przewodniczący CKW ZSRR. 29 listopada natomiast premier Herriot i ambasador Dowgalewski złożyli podpisy pod sowiecko-francuskim układem o niestosowaniu przemocy ${ }^{67}$.

66 Telegram Becka do poselstwa w Bukareszcie z [X 1932] (stąd cytat), HIA. Rumunia. Tel. osob. ks. 1; telegram Patka do MSZ z 16 X 1932, PDD 1932, s. 610-611; list Litwinowa do Stalina z 14 X 1932, SRO, s. 400; telegram Litwinowa do Rosenberga z 15 X 1932 r. DVP, t. XV, s. 570; notatka z rozmowy Litwinowa z Patkiem z 16 X 1932, ibidem, s. 576, zob. też telegram Becka do poselstwa w Bukareszcie z 14 X 1932, PDD 1932, s. 602; M. I. Mel'tûhov, op. cit., s. 161.

67 Telegram Becka do poselstwa w Bukareszcie z 24 X (nr 120), 26 X (nr 121) 1932, HIA. Rumunia. Ks. szyf., nr 6, p. 2, f. 3; telegram Kobylańskiego do MSZ z 24 XI 1932, nr 139, ibidem; telegram Titulescu do poselstwa w Warszawie z 5 XI 1932 (nr 4001), AMAE, 71/1920-1944 Polonia. Vol. 54, k. 287-288; J. Beck, op. cit., s. 33; A. Skrzypek, Zagadnienia rumuńskie..., s. 194; F. C. Nanu, op. cit., 
Wzrost w Niemczech na przełomie lat dwudziestych i trzydziestych tendencji rewizjonistycznych sprawił, iż Francja, która po 1925 r. gotowa była współpracować z nimi i Wielką Brytanią w utrwaleniu ładu lokarneńsko-genewskiego, zaczęła poszukiwać asekuracji przed zagrożeniem płynącym ze strony wschodniego sąsiada. Jako partner do współpracy w tym zakresie jawił się Związek Sowiecki, który zaniepokojony rosnącymi w Rzeszy wpływami antysowiecko nastawionej skrajnej prawicy liczył się z porzuceniem przez Berlin realizowanego od 1922 r. kursu współdziałania z Moskwą. Dla Polski zagrożonej niemieckim rewizjonizmem ta ewolucja stosunków między Francją, Rzeszą i ZSRR wydawała się korzystna. Ulegało bowiem osłabieniu szkodliwe dla jej interesów współdziałanie z jednej strony Paryża i Berlina z drugiej Berlina i Moskwy. Stąd też pozytywnie przyjęto w Warszawie inicjatywę Francji podpisania z ZSRR paktu o nieagresji i zdecydowano o wznowieniu zamrożonych od 1927 r. pertraktacji z Moskwą w sprawie takiego samego układu.

Zamiarem dyplomacji RP stało się doprowadzenie do jednoczesnego podpisania z ZSRR paktów o nieagresji przez Polskę, Finlandię, Estonię, Łotwę i Rumunię. Kooperacja w tym zakresie zachodnich sąsiadów Związku Sowieckiego miała służyć wzmocnieniu pozycji negocjacyjnej poszczególnych państw względem Moskwy, a w dalszej perspektywie stabilizacji stosunków w Europie Środkowo-Wschodniej. Czynnikiem sprzyjającym realizacji tych planów było uzależnienie przez Francję podpisania układu z ZSRR od wcześniejszego dojścia do skutku paktów sowiecko-polskiego i sowiecko-rumuńskiego.

Jak zaznaczono już w części I artykułu, Rumuni oceniali pakt o nieagresji ze Związkiem Sowieckim jako mało pożyteczny dla siebie. Obawiali się uzewnętrznienia w układzie spornego charakteru przynależności Besarabii oraz otwarcia Rumunii na wpływy komunistyczne w rezultacie nawiązania stosunków dyplomatycznych z ZSRR. Stąd też wzdragali się przed podjęciem pertraktacji i ulegli dopiero wskutek nacisku Francji i Polski. Negocjacje podjęte w Rydze w styczniu 1932 r. rozbiły się o sowiecki warunek wprowadzenia do tekstu układu sprawy Besarabii. Mimo zabiegów Warszawy, rozmów nie udało się wznowić. Zaważyły na tym głównie opozycyjne wobec paktu stanowisko Titulescu oraz niechętne nastawienie premiera Tardieu.

Inicjatywę przezwyciężenia impasu podjął w kwietniu 1932 r. marszałek Piłsudski. W czasie wizyty w Bukareszcie wskazał Rumunom możliwość podpisania przez Polskę paktu o nieagresji bez czekania na nich, argumentując to finalizacją układów o nieagresji przez państwa bałtyckie. Niewiele zmieniło to w stanowisku Rumunii, zwłaszcza, że minister Ghica został w tym czasie zupełnie usunięty w cień przez Titulescu, który w swoim niewzruszonym nastawieniu wobec paktu z ZSRR nadal posiadał wsparcie premiera Tardieu. Postawa Francji była w tym czasie niejednolita, gdyż Quai d'Orsay nadal stało na stanowisku szukania w bezpośrednich negocjacjach

s. 158; H. Bułhak, op. cit., s. 330; V. Moisuc, op. cit., s. 327; Â. Kopanskij, I. È. Levit, op. cit., s. 112; zob. telegramy Szembeka do MSZ z 25 X (nr 123), 26 X (nr 124) 1932, HIA. Rumunia. Ks. szyf., nr 6, p. 2, f. 3; raport Davidescu do MSZ z 9 XI 1932. AMAE, 71/1920-1944 Polonia. Vol. 18, k. 154-155. 
rumuńsko-sowieckich kompromisowej formuły paktu. Linia polityczna Francji stała się bardziej jednorodna po wyborach w lecie 1932 r. i dojściu do władzy premiera Herriota, zwolennika osiągnięcia kompromisu między Moskwą a Bukaresztem. Pod wpływem Paryża król Karol oraz niektórzy ministrowie z gabinetu Iorgi zaczęli się skłaniać ku wznowieniu negocjacji. Jednakże nie przyniosło to żadnych konkretnych rezultatów poza deklaracjami o gotowości podpisania paktu przy pośrednictwie Polski lub Francji. Politycy i dyplomaci RP podejmowali wysiłki w tym kierunku, zabiegając w rozmowach z Rosjanami o wypracowanie formuły mogącej zadowolić Rumunów. Ci jednak pryncypialnie odmawiali dyskusji na temat wprowadzenia do paktu nawet najogólniejszej wzmianki o sporze. Sytuacji tej początkowo nie zmieniło dojście do władzy w Bukareszcie gabinetu Vaida-Voevoda, który wprawdzie deklarował chęć osiągnięcia consensusu z Moskwą, ale nie potrafił sformułować własnych warunków porozumienia z ZSRR, a główne wysiłki podejmował w kierunku przesunięcia przez Polskę terminu podpisania jej paktu z Sowietami. Warszawa argumentowała, iż dalsze odraczanie jest niemożliwe ze względu na państwa bałtyckie, które już swoje pakty z ZSRR podpisały, a Polska i tak straciła okazję do jednoczesnej z nimi finalizacji własnego układu z ZSRR. Z drugiej strony oferowano Rumunom zwlekanie z jego ratyfikacją, aby mogli oni zawrzeć układ ze Związkiem Sowieckim. Dyplomaci RP kontynuowali także działania pośredniczące i prowadzili rozmowy tak z politykami rumuńskimi, jak i sowieckimi.

Vaida-Voevod wykazywał pewne inklinacje do szukania formuły kompromisowej. Naraził się jednak Titulescu, który podjął ataki na rząd. Pragnąc go zneutralizować, premier wysunął propozycję podpisania sformułowanej przez Titulescu nowej wersji paktu. Stawiała ona pod znakiem zapytania dotychczasowe ustalenia w sprawie paktu i nie zyskała uznania Litwinowa, który uznał takie działania za niepoważne. Pewien postęp zarysował się w drugiej połowie września, gdy udało się Patkowi doprowadzić do pierwszego spotkania od czasu rozmów w Rydze przedstawicieli Rumunii i ZSRR: posła Cădere i komisarza Litwinowa. Rozmowa przeprowadzona w pociągu między Białymstokiem a Warszawą nie przyniosła wprawdzie bezpośrednich efektów, gdyż Rumun nie posiadał pełnomocnictw do prowadzenia negocjacji. Jednak obie strony pod wpływem zabiegów dyplomacji polskiej i francuskiej zdecydowały się kontynuować wymianę zdań w Genewie za pośrednictwem wspomnianych dyplomatów. Tym razem Cǎdere został wyposażony w pełnomocnictwo parafowania paktu o nieagresji. Negocjacje doprowadziły do zasadniczych uzgodnień treści paktu. Nie udało się jednak osiągnąć porozumienia w sprawie formuły obecności w tekście określenia „spory”. Bliskie wydawało się przyjęcie zaproponowane przez negocjatora rumuńskiego we własnym imieniu, sformułowanie, iż pakt „nie przesądza obecnych i przyszłych sporów między [stronami]”. Takie brzmienie nie zyskało uznania Palatul Sturdza. Rokowania nie zostały jednak zerwane, lecz jedynie zawieszone. Dyplomacja polska z optymizmem odnosiła się do szans końcowego porozumienia. Pertraktacje nie były jednak po myśli Titulescu, który z tego powodu zaatakował rząd Vaida-Voevoda, a następnie podał się do dymisji z funk- 
cji posła rumuńskiego w Lidze Narodów oraz przedstawiciela w Londynie. Próba spacyfikowania Titulescu i wprowadzenie go do Rady Ministrów przyśpieszyły jej upadek. Nowy szef dyplomacji bowiem jeszcze przed objęciem swoich obowiązków skrytykował prowadzone w Genewie pertraktacje i zadeklarował, iż nie wyraża zastrzeżeń odnośnie do zawarcia przez Francję i ratyfikację przez Polskę ich układów o nieagresji z ZSRR. W poufnej zaś rozmowie z politykami francuskim oświadczył, iż nie będzie dążył do finalizacji paktu z Moskwą, lecz jedynie pozorował negocjacje, aby wina za ich zerwanie spadła na Rosjan. W tej sytuacji Beck poinformował Maniu - nowego szefa rządu - iż Polska nie zamierza być narzędziem w grze prowadzonej przez szefa rumuńskiej dyplomacji. Prezydentowi Mościckiemu nie pozostawało zatem nic innego, jak ratyfikować 26 listopada 1932 r. pakt o nieagresji ze Związkiem Sowieckim.

Wysiłki dyplomacji polskiej doprowadzenia do stworzenia bloku państw finalizujących jednocześnie pakty o nieagresji z ZSRR zakończyły się fiaskiem na odcinku Rumunii. Władze tego kraju nie podzielały przekonania polskich czynników kierowniczych, iż pakt w sposób znaczący zwiększy bezpieczeństwo Rumunii od strony ZSRR i będzie elementem stabilizującym sytuację międzynarodową w Europie Środkowo-Wschodniej. Obawiały się zwłaszcza wzmiankowania w pakcie kwestii besarabskiej, co mogłoby, ich zdaniem, zagrozić integralności Królestwa. Groźba izolacji na arenie międzynarodowej oraz naciski ze strony Polski i Francji powodowały, iż dyplomacja rumuńska zaczęła w końcu brać pod uwagę możliwość zawarcia paktu oraz podjęła rozmowy z ZSRR w Rydze i Genewie. Nie przyniosły one finalizacji układu, choć szanse na to były duże w trakcie negocjacji w Genewie. Na ich niepowodzeniu zaważyły opory rumuńskiego MSZ przed wprowadzeniem do paktu choćby najdrobniejszej sugestii, iż między Bukaresztem a Moskwą istnieje spór o Besarabię oraz negatywne nastawienie Titulescu przejawiane na przestrzeni 1932 roku. W postawie tego ostatniego, obok obaw bliskich także innym politykom rumuńskim, dochodziła do głosu urażona ambicja, która kazała mu najpierw zwalczać pakt, nie przebierając w środkach, a następnie storpedować go w sytuacji, gdy zaczęły się rysować realne widoki jego finalizacji.

Poland and the question of the Romanian-Soviet pact of non-aggression in the years 1931-1932 (2)

In April 1932, Józef Piłsudski actively sought to solve the impasse, which occurred following the negotiations in Riga. During his visit to Bucharest, he informed the Romanian side about the possibility of Poland signing a non-aggression pact without waiting for them, justifying this decision with the conclusion of similar agreements by the Baltic states. However, little did this affect the reluctant stance of Romania, which was supported by the French Prime Minister André Tardieu. Nonetheless, the attitude of the French side was not uniform, as their Ministry of Foreign Affairs advocated for the elaboration of a compromise version of the pact through direct Romanian-Soviet negotiations. France's stance became more homogeneous after the election in the summer of 1932 and the coming to power of Prime Minister Edouard Herriot, a supporter 
of compromise between Moscow and Bucharest. Under the influence of Paris, King Charles I of Romania and several ministers from Nicolae Iorgi's cabinet began to lean towards the resumption of negotiations. However, no tangible results were obtained other than declarations of readiness to conclude a pact under the supervision of Poland or France. Several Polish politicians and diplomats made efforts in this direction by attempting to motivate the Russians towards finding a compromise solution that would satisfy the Romanians; however, the Russian side firmly refused to debate even the most general mention of "disputes" between the USSR and Romania. The situation initially remained unaffected by the coming to power of Alexandru Vaida Voevod in Bucharest, who in spite of his declared desire to achieve consensus with Moscow, failed to formulate his own terms of the agreement with the USSR, and focused his efforts on convincing the Polish authorities to postpone the signing of their pact with the Soviet Union. The Polish side argued that further delaying was impossible, given that the Baltic states had already concluded their agreements with the USSR, which meant Poland had already lost the opportunity to conclude theirs at that same time. On the other hand, the Polish side promised to delay its ratification, in order to enable Bucharest to sign its own pact with the Soviet Union.

Eventually, Vaida Voevod began to show some inclination towards finding compromise. However, he fell into disfavour with Nicolae Titulescu, an influential personality in the Romanian diplomacy, who expressed criticism of the government. In an attempt to neutralise him, the Prime Minister suggested signing an amended version of the pact proposed by Titulescu, but this put the arrangements made so far into question and did not meet with the approval of the Soviet Commissar for Foreign Affairs, Maxim Litvinov, who considered such measures frivolous. The negotiations between Romania and the USSR were resumed in Geneva in early October 1932. Essential arrangements regarding the contents of the pact were established, yet no compromise was reached regarding the appearance of the term "disputes" and its form in the document. However, the negotiations were only suspended rather than broken off. The Polish side was optimistic regarding the chances for a final agreement. Unfortunately, in the meantime, Titulescu had become the new head of Romanian diplomacy. Even prior to taking up his duties, he condemned the negotiations conducted in Geneva and declared that he had no objection concerning the conclusion and ratification of the non-aggression pacts with the USSR by France and Poland. At the same time, in a confidential conversation with French politicians, he declared that he would not seek finalising the pact with Moscow, only pretending to negotiate instead so that the blame for the fiasco would be put on the Russians. In this situation, the Polish Vice Minister of Foreign Affairs, Józef Beck, informed Bucharest that Poland would not tolerate being used as a pawn by the head of Romanian diplomacy, while the Polish President, Ignacy Mościcki, ratified the Polish-Soviet non-aggression pact on 26 November 1932.

Translated by Jakub Perliński

Польша и румыно-советский пакт о ненападении в 1931-1932гг. (2)

Маршал Юзеф Пилсудский выступил с инициативой преодолеть тупик, который наступил после переговоров в Риге в апреле 1932г. Во время визита в Бухарест, он указал румынам на возможность подписания Польшей пакта о ненападении, не дожидаясь румынской стороны, и аргументируя это завершением таких же переговоров прибалтийскими государствами. Это не намного изменило неохотное отношение Румынии, у которой была поддержка премьер-министра Франции Андре Тардьё. Позиция Парижа в это время была неоднородной, так как местный МИД придерживался мнения, что надо искать компромиссную формулу пакта в непосредственных румыно-советских переговорах. Политическая линия Франции стала более однородной после выборов летом 1932г. и прихода к власти 
премьер-министра Эдуара Эррио, сторонника достижения компромисса между Москвой и Бухарестом. Под влиянием Парижа румынский король Кароль I, а также некоторые министры из кабинета Николае Йорга стали склоняться к возобновлению переговоров. Однако это не принесло никаких конкретных результатов, кроме деклараций о готовности подписать пакт при посредничестве Польши или Франции. Польские политики и дипломаты предпринимали усилия в этом направлении, ходатайствуя в разговорах с советской стороной о выработке формулы, которая могла бы удовлетворить румын. Однако те принципиально отказывались дискутировать на тему введения в пакт даже самого общего упоминания о „споре” с СССР.

Изначально, эта обстановка не изменилась из-за прихода к власти в Бухаресте кабинета Александру Вайда-Воевода, который хотя и декларировал желание достичь консенсуса с Москвой, но не умел сформулировать собственных условий соглашения с СССР, а главные усилия направил на то, чтобы Польша передвинула термин подписания ее договора с Советами. Варшава аргументировала, что дальнейшая отсрочка невозможна, учитывая что прибалтийские государства уже подписали свои пакты с СССР, а Польша и так упустила случай, чтобы одновременно с ними финализировать собственное соглашение с СССР. С другой стороны, Польша предложила румынам промедлить с ратификацией собственного пакта, для того чтобы они могли заключить свой договор с Советским Союзом.

Вайда-Воевод стал, наконец-то, проявлять некоторую склонность к поискам компромиссной формулы. Однако он вооружил против себя Николае Титулеску - влиятельную персону в румынской дипломатии, который атаковал правительство. Премьер-министр, желая его нейтрализовать, выдвинул предложение подписать, составленную Титулеску, новую версию пакта. Она ставила под вопрос прежние решения по пакту и не снискала одобрения советского народного комиссара по иностранным делам Максима Литвинова, который признал такие действия несерьезными. Румыно-советские переговоры возобновились в начале октября 1932г. в Женеве, когда удалось выработать основные согласования содержания пакта. Не было достигнуто соглашение о формуле наличия в тексте определения „споры”. Переговоры, однако, не были сорваны, но лишь только приостановлены.

Польская дипломатия с оптимизмом относилась к шансам на финальное соглашение. Однако новым главой румынской дипломатии стал Титулеску. Еще до вступления в свои обязанности он раскритиковал переговоры, которые велись в Женеве и заявил, что он у него нет возражений против заключения Францией и ратификации Польшей их пактов о ненападении с СССР. А в конфиденциальной беседе с французскими политиками он заявил, что не будет стремиться к заключению пакта с Москвой, но лишь создавать видимость переговоров, чтобы вина за их сорвание была взвалена на советскую сторону. В такой ситуации польский вице-министр иностранных дел Юзеф Бек проинформировал Бухарест, что Польша не намерена быть орудием в игре главы румынской дипломатии, а президент Польской республики Игнаций Мосцицикий 26 ноября 1932г. ратифицировал польско-советский пакт о ненападении.

Перевод Агнешка Поспишыль

\section{Bibliografia}

Beck J., Ostatni raport, przedmową poprzedził M. Wojciechowski, Warszawa 1987.

Behind closed doors. Secret papers on the failure of Romanian-Soviet negotiations 1931-1932, tłum. i wstęp W. M. Bacon, Stanford 1979.

Bold E., Locovei R. O., Relaţii româno-sovietice (1918-1941), Iaşi 2008. 
Bułhak H., Polska a Rumunia 1918-1939, [w:] Przyjaźnie i antagonizmy. Stosunki Polski z państwami sąsiednimi w latach 1918-1939, red. J. Żarnowski, Warszawa 1977.

Bystricky V., Deák L., Európa na prelome. Diplomatické a politické vztahy v rokoch 1932-1933, Bratislava 1974.

Călinescu A., Însemări politice 1916-1939, ediţie A. G. Savu, Bucureşti 1990.

Dessberg F., La Roumanie et la Pologne dans la politique soviétique de la France. La difficulté d'établir un «front uni» (1924-1935), „Revue Historique des Armées” 2006, nr 3 (244).

Documents diplomatiques français 1932-1939, 1-ère serie (1932-1935), t. 1 (9 juillet-14 novembre 1932), Paris 1963.

Dokumenty i materiały do historii stosunków polsko-radzieckich, t. V, maj 1926-grudzień 1932, oprac. T. Cieślak i in., Warszawa 1966.

Dokumenty vnešnej politiki SSSR. T. 15. 1 ânvarâ-31 dekabrâ 1932 g., red. G. K. Deev i in., Moskva 1969.

Dubicki A., Nicolae Titulescu. Portret polityka i dyplomaty, Łomianki 2010.

Gafencu G., Insemnări politice 1929-1939, oprac. i posłowie S. Neagoe, Bucureşti 1991.

Gmurczyk-Wrońska M., Negocjacje polsko-sowieckie o pakt o nieagresji w roku 1927 i w latach 1931-1932, „Dzieje Najnowsze” 2012.

Hrenciuc D., România şi Polonia 1932-1939. Relaţii politice şi diplomatice, Iaşi 2005.

Ken O. N., Rupasov N. I., Politbûro CK VKP (b) i otnošeniâ SSSR s zapadnymi sosednimi gosudarstvami (konec 1920-1930-h gg.). Problemy. Dokumenty. Opyt kommentariâ, Čast' 1: 1928-1934, Sankt Petersburg 2000.

Kopanskij Â. M., Levit I. Ė., Sovetsko-rumynskie otnošeniâ 1929-1934 gg. (ot podpisania Moskovskogo protokola do ustanovleniâ diplomatičeskih otnošenij), Moskva 1971.

Krasuski J., Tragiczna niepodległość. Polityka zagraniczna Polski w latach 1919-1945, Poznań 2000.

La Grande Roumanie alliée de la France. Une péripétie diplomatique des Années Folles? (1919-1933), oprac. T. Sandu, Montréal 1999.

Łopatniuk S., Nieznane dokumenty archiwalne z historii polsko-radzieckich rokowań o pakt o nieagresji, ZDSPR, t. V, 1969.

Manoilescu M., Memorii, Vol. II, ediţie îngrijită, prefaţă, note şi indice de V. Dinu, Bucureşti 1993.

Mel'tûhov M. I., Bessarabskij vopros meždu mirovymi vojnami 1917-1940, Moskva 2010.

Mironov A.-M., Vremea încercărilor. Relațiile româno-sovietice 1930-1940, București 2013.

Moisuc V., Premisele izolării politice a României 1919-1940, București 1991.

Nanu F. C., Politica externă a României 1918-1933, traducere de L. Roşca şi E. Ungureanu, Iaşi 1993.

Pădureac L., Relaţiile româno-sovietice 1917-1934, Chişinău 2003.

Politbiuro TsK RKP(b)-VKP(b) i Evropa. Resheniia „osoboi papki”, 1923-1939, red. G. Adibekov i in., Moskva 2001.

Polskie Dokumenty Dyplomatyczne 1932, red. K. Kania, Warszawa 2011.

Sandu T., Système de sécurité français en Europe centre-orientale. L'exemple roumain 1919-1933, Paris-Montréal 1999.

Scurtu I., Buzatu G., Istoria Românilor în secolul XX (1918-1948), București 1999.

Ševâkov A., Sovetsko-rumynskie otnošeniâ i problema evropejskoj bezopasnosti, 1932-1939, Moskva 1977.

Skrzypek A., Polsko-radziecki pakt o nieagresji z 1932 r., ZDSPR, t. XIII, 1976.

Skrzypek A., Zagadnienia rumuńskie w stosunkach polsko-radzieckich w latach 1932-1938. Z dziejów stosunków polsko-radzieckich (dalej: ZDSPR), t. XI-XII, Studia i materiały, Warszawa 1975.

Sovetsko-rumynskie otnošeniâ. Dokumenty i materialy 1917-1934, t. 1, red. A. A. Avdeev i in., Moskva 2000.

Vaida-Voevod A., Memorii, Vol. II, prefaţă, ediţie îngrijită, note şi comentarii de A. Şerban, Cluj-Napoca 2006.

Wołos M., Francja - ZSRR. Stosunki polityczne w latach 1924-1932, Toruń 2004. 
Henryk Walczak - doktor habilitowany, profesor Uniwersytetu Szczecińskiego, specjalizuje się w badaniach dotyczących stosunków polsko-rumuńskich w okresie międzywojennym, biografistyce i edycji źródeł; autor m.in. monografii Sojusz z Rumuniq w polskiej polityce zagranicznej w latach 1918-1931, Szczecin 2008; współredaktor i współautor opracowania Od Moraczewskiego do Składkowskiego. Gabinety Polski Odrodzonej 1918-1939, Szczecin 2010, współredaktor Dziennika Juliusza Zdanowskiego, t. I-VI, Szczecin 2013-2015 oraz Wspomnień ks. Henryka Hilchena, t. I-II, Szczecin 2014. (Henryk_Walczak@poczta.fm) 